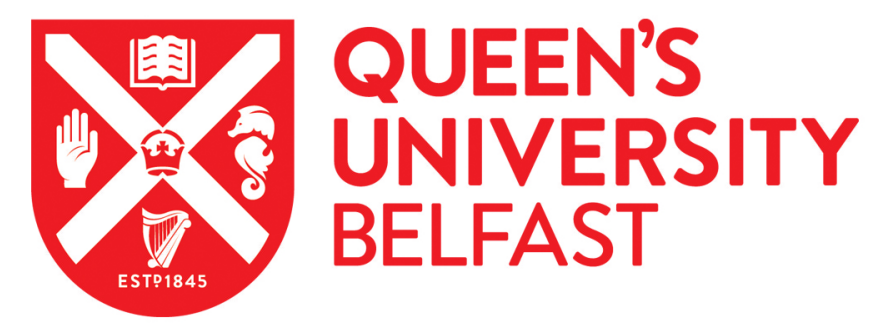

\title{
Web crippling behaviour of cold-formed steel channel sections with web holes subjected to Interior-one-flange loading condition-part I: experimental and numerical investigation
}

Lian, Y., Uzzaman, A., Lim, J. B. P., Abdelal, G., Nash, D., \& Young, B. (2017). Web crippling behaviour of coldformed steel channel sections with web holes subjected to Interior-one-flange loading condition-part I: experimental and numerical investigation. Thin-Walled Structures, 111, 103-112.

https://doi.org/10.1016/j.tws.2016.10.024

\section{Published in:}

Thin-Walled Structures

Document Version:

Peer reviewed version

Queen's University Belfast - Research Portal:

Link to publication record in Queen's University Belfast Research Portal

\section{Publisher rights}

(c) 2017 Elsevier Ltd. This manuscript version is made available under the CC-BY-NC-ND 4.0 license http://creativecommons.org/licenses/bync-nd/4.0/ which permits distribution and reproduction for non-commercial purposes, provided the author and source are cited.

\section{General rights}

Copyright for the publications made accessible via the Queen's University Belfast Research Portal is retained by the author(s) and / or other copyright owners and it is a condition of accessing these publications that users recognise and abide by the legal requirements associated with these rights.

Take down policy

The Research Portal is Queen's institutional repository that provides access to Queen's research output. Every effort has been made to ensure that content in the Research Portal does not infringe any person's rights, or applicable UK laws. If you discover content in the

Research Portal that you believe breaches copyright or violates any law, please contact openaccess@qub.ac.uk. 


\title{
WEB CRIPPLING BEHAVIOUR OF COLD-FORMED STEEL
}

CHANNEL SECTIONS WITH WEB HOLES SUBJECTED TO

INTERIOR-ONE-FLANGE LOADING CONDITION-PART I:

\section{EXPERIMENTAL AND NUMERICAL INVESTIGATION}

\author{
Ying Lian ${ }^{\mathrm{a}}$, Asraf Uzzaman ${ }^{\mathrm{b}}$, James B.P Lim ${ }^{\mathrm{a}, \mathrm{c}}$, Gasser Abdelal ${ }^{\mathrm{d}}$,
}

$$
\text { David Nash }^{\mathrm{b}} \text {, Ben Young }{ }^{\mathrm{e}}
$$

\author{
a SPACE, David Keir Building, Queen's University, Belfast, BT9 5AG, UK \\ b Department of Mechanical and Aerospace Engineering, The University of Strathclyde, 75 Montrose Street, Glasgow G1 1XJ , UK \\ c Civil \& Environmental Engineering, The University of Auckland, 20 Symonds Street, Auckland, New Zealand \\ d Department of Mechanical and Aerospace Engineering, Queen's University, Belfast, BT9 5AH, UK \\ e Department of Civil Engineering, The University of Hong Kong, Pokfulam Road, Hong Kong
}

\begin{abstract}
Web openings are increasingly used in cold-formed steel beam members of buildings to facilitate ease of services. In this paper, a combination of tests and non-linear finite element analyses is used to investigate the effect of such holes on web crippling under the interior-one-flange (IOF) loading condition; the cases of both flange fastened and flange unfastened to the bearing plate are considered. The results of 61 web crippling tests are presented, with 18 tests conducted on channel sections without web openings and 43 tests conducted on channel sections with web openings. In the case of the tests with web openings, the hole was either located centred beneath the bearing plate or having a horizontal clear distance to the near edge of the bearing plate. A good agreement between the tests and finite element analyses was obtained in term of both strength and failure modes.
\end{abstract}

\section{Keywords}

Cold-formed steel; Web crippling; Finite element analysis; web hole; Channel section; 


\section{Nomenclature}

A Web holes ratio;

$a \quad$ Diameter of circular web holes;

$a_{L H S} \quad$ Diameter of circular web holes positioned left hand side of specimen;

$a_{R H S} \quad$ Diameter of circular web holes positioned right hand side of specimen;

$b_{f} \quad$ Overall flange width of section;

$b_{l} \quad$ Overall lip width of section;

COV Coefficient of variation;

d Overall web depth of section;

E Young's modulus of elasticity;

FEA Finite element analysis;

$f_{\mathrm{y}} \quad$ Material yield strength;

$h \quad$ Depth of the flat portion of web;

$L \quad$ Length of the specimen;

$N \quad$ Length of the bearing plate;

$P \quad$ Experimental and finite element ultimate web crippling load per web;

$P_{\text {EXP }} \quad$ Experimental ultimate web crippling load per web;

$P_{\text {FEA }} \quad$ Web crippling strength per web predicted from finite element (FEA);

$P_{m} \quad$ Mean value of tested-to-predicted load ratio;

$R \quad$ Reduction factor;

$R_{\mathrm{P}} \quad$ Proposed reduction factor;

$r_{\mathrm{i}} \quad$ Inside corner radius of section;

$t \quad$ Thickness of section;

$x \quad$ Horizontal clear distance of the web holes to the near edge of the bearing plate; 
Elongation (tensile strain) at fracture;

$\sigma_{0.2}$

Static $0.2 \%$ proof stress; and

$\sigma_{u}$

Static ultimate tensile strength. 


\section{Introduction}

Web openings are increasingly used in cold-formed steel members to facilitate ease of services in buildings. In such members, web crippling can occur at points of concentrated loads [1] (see Fig. 1), and also influenced by the size and position of the openings.

Strength reduction factor equations have recently been proposed by Uzzaman et al. [2-5] for the web crippling strength of cold-formed steel channel sections with circular holes in the web under the end-two-flange (ETF) and interior-two-flange (ITF) loading conditions. This paper extends the work of Uzzaman et al. [2-5] to consider the interiorone-flange (IOF) loading condition for cold-formed steel channel sections with circular holes in the web. The web crippling strength of lipped channel sections for the interiorone-flange (IOF) loading condition, as shown in Fig. 2, are considered. The cases of both flange fastened and flange unfastened to the bearing plate are considered, for cold-formed steel channel sections having circular web holes located centred beneath the bearing plate and also with a horizontal clear distance to the near edge of the bearing plate.

In the literature, for the IOF loading condition, $\mathrm{Yu}$ and Davis [6] previously considered the case of both circular and square web openings located and centred beneath the bearing plate with flange unfastened to bearing plate. It should be noted, however, that the test arrangement reported did not use the new established IOF testing procedure [7] in which back-to-back channel section specimens were loaded, but instead used two channel sections connected through their lips. Nevertheless, these tests remain the only reported in the literature for the IOF loading condition where the holes are located and centred beneath the bearing plate. For the circular holes, a total of 10 tests were reported, and all tested with a bearing length of $89 \mathrm{~mm}$. A strength reduction factor equation was proposed but was limited to the aforementioned bearing length. 
Again for the IOF loading condition, LaBoube et al. [8] have also considered the case of a circular hole that has a horizontal clear distance to the near edge of the bearing plate, but only for the case where the flange is fastened to the bearing plate. The strength reduction factor equation proposed by LaBoube et al. [8] was subsequently adopted by the North American Specification (NAS) [9] for cold-formed steel sections. This strength reduction factor equation, however, was limited to thicknesses ranged from $0.83 \mathrm{~mm}$ to $1.42 \mathrm{~mm}$. Other similar work described in the literature include that of Sivakumaran and Zielonka [10] who considered rectangular web openings located and centred beneath the bearing plate under the interior-one-flange loading condition, and Zhou and Young [11] who proposed strength reduction factor equations for aluminium alloy square sections with circular web openings located and centred beneath the bearing plates under end- and interior-two flange loading conditions. Recent research on web crippling of cold-formed steel channel sections, other than that by Uzzaman et al. [2-5] who again considered only the two-flange loading conditions, has not covered the case of holes [12-15].

In this study, a test programme was conducted on lipped channel sections with circular web holes subject to web crippling. In addition, the general purpose finite element analysis (FEA) program ABAQUS [16] was used for the numerical investigation. The finite element model (FEM) included geometric and material non-linearities; the results of the finite element analysis were verified against laboratory test results. Both the failure loads as well as the modes of failure predicted from the finite element analyses were in good agreement with the laboratory test results.

\section{Experiment investigation}

\subsection{Test specimens}

A test programme was conducted on lipped channel sections, as shown in Fig. 3, with circular web holes subjected to web crippling. Fig. 3 shows the definition of the 
symbols used to describe the dimensions of the cold-formed steel lipped channel sections considered in the test programme. Fig. 4 shows a schematic view of the test set-up. As can be seen from Fig. 4, each test comprised a pair of channel sections with load transfer blocks bolted between them. Washer plates of thickness $6 \mathrm{~mm}$ were bolted to the outside of the webs of the channel sections.

The size of the web holes was varied in order to investigate the effect of the web holes on the web crippling behaviour. Circular holes with a nominal diameter $(a)$ ranging from $55 \mathrm{~mm}$ to $179 \mathrm{~mm}$ were considered in the experimental investigation. The ratio of the diameter of the holes to the depth of the flat portion of the webs $(a / h)$ was $0.2,0.4$ and 0.6. All test specimens were fabricated with web holes located at the mid-depth of the webs and centred beneath the bearing plate and with a horizontal clear distance to the near edge of the bearing plate (x), as shown in Fig. 4(b).

Channel sections without holes were also tested. The test specimens consisted three different section sizes, having nominal thicknesses ranged from $1.2 \mathrm{~mm}$ to $2.0 \mathrm{~mm}$; the nominal depth of the webs and the flange widths ranged from $142 \mathrm{~mm}$ to $302 \mathrm{~mm}$. The measured web slenderness $(h / t)$ values of the channel sections ranged from 109 to 157.8 . The specimen lengths $(L)$ were determined according to the NAS [9]. Generally, the distance between bearing plates was set to be 1.5 times the overall depth of the web (d) rather than 1.5 times the depth of the flat portion of the web $(h)$, the latter being the minimum specified in the specification.

Tables 1 and 2 show the measured test specimen dimensions for the flange unfastened and fastened to the bearing plate, respectively, using the nomenclature defined in Fig. 2 and Fig. 3 for the IOF loading condition. The bearing plates were fabricated using high strength steel having a nominal yield strength of $560 \mathrm{MPa}$ and a thickness of $25 \mathrm{~mm}$. Three lengths of bearing plates $(N)$ were used: $100 \mathrm{~mm}, 120 \mathrm{~mm}$ and $150 \mathrm{~mm}$. 


\subsection{Specimens labelling}

In Tables 1 and 2, the specimens were labelled such that the nominal dimension of the specimen and the length of the bearing plates, as well as the ratio of the diameter of the holes to the depth of the flat portion of the webs $(a / h)$ could be identified from the label. For example, the labels "202x65x15-t1.4-N100-A0-FR”, "202x65x15-t1.4-N100MA0.4-FR" “202x65x15-t1.4-N100-A0-FX” and "202x65x15-t1.4-N100-MA0.4-FX" are explained as follows:

- The first four notations defined the nominal dimensions $\left(d \times b_{\mathrm{f}} \times b_{1}-\mathrm{t} 1.4\right)$ of the specimens in millimetres (e.g. $202 \times 65 \times 15$-t 1.4 means $d=202 \mathrm{~mm} ; b_{\mathrm{f}}=65 \mathrm{~mm}$; $b_{1}=15 \mathrm{~mm}$ and $\left.t=1.4 \mathrm{~mm}\right)$.

- $\quad$ "N100" indicates the length of bearing in millimetres (i.e. $100 \mathrm{~mm}$ ).

- $\quad$ "A0.2", "A0.4", "A0.6" and "A0.8" represent the ratios of the diameter of the holes to the depth of the flat portion of the webs $(a / h)$ i.e. A0.2 means $\mathrm{a} / \mathrm{h}=0.2$; 0.6 means $\mathrm{a} / \mathrm{h}=0.6$. In all cases, the holes are located at the mid-depth of the web and with a horizontal clear distance to the near edge of the bearing plate $(x=0.2 h)$. Eighteen tests were conducted on the channel section specimens without web holes, and these are denoted by "A0".

- "MA0.2", "MA0.4" and "MA0.6", the letter "M" indicate web holes located centred beneath the bearing plate.

- "FR" represents flange unfastened to the bearing plates and "FX" represents flange fastened to the bearing plate.

\subsection{Material properties}

Tensile coupon tests were carried out to determine the material properties of the channel sections. The tensile coupons were taken from the centre of the web plate in the longitudinal direction of the untested specimens. The tensile coupons were prepared and 
tested according to the British Standard for tensile testing of metallic materials [17]. The coupons were tested in a MTS displacement controlled testing machine using friction grips. Two strain gauges and a calibrated extensometer of $50 \mathrm{~mm}$ gauge length were used to measure the longitudinal strain. The material properties obtained from the tensile coupon tests are summarised in Table 3 , which includes the measured static $0.2 \%$ proof stress $\left(\sigma_{0.2}\right)$ and the static tensile strength $\left(\sigma_{u}\right)$ based on gauge length of $50 \mathrm{~mm}$.

\subsection{Test rig and procedure}

The specimens were tested under the interior-one-flange (IOF) loading condition specified in the NAS [9], as shown in Fig.4(a), Fig. 4(b), Fig. 5(a), Fig. 6(a), Fig. 7(a) and Fig. 8(a), where two channel sections were used to provide symmetric loading. The specimens were bolted to load transfer blocks at each end of the specimens. A bearing plate was positioned at the mid-length of the specimens. Hinge supports were simulated by two half rounds in the line of action of the force and teflon pads. Two displacement transducers (LVDTs) were used to measure the vertical displacements. In addition, two displacement transducers were positioned at the two edges of bearing plate to measure the vertical displacements. A servo-controlled hydraulics testing machine was used to apply a concentrated compressive force to the test specimens. Displacement control was used to drive the hydraulic actuator at a constant speed of $0.05 \mathrm{~mm} / \mathrm{min}$. The load was applied through bearing plate. All the bearing plates were fabricated using high strength steel having a nominal yield stress of $560 \mathrm{MPa}$, and thickness of $25 \mathrm{~mm}$. In the experimental investigation, three different lengths of bearing plates $(N)$ were used, namely, $100 \mathrm{~mm}, 120 \mathrm{~mm}$ and $150 \mathrm{~mm}$. The experimental investigation also considered flange of the channel section specimens fastened or unfastened to the bearing plate, as shown in Fig. 4(c) and (d).For the case of the flange fastened test set-up, the flange was bolted to the bearing plate. 


\subsection{Test results}

A total of 61 specimens were tested under the interior-one-flange (IOF) loading condition. The experimental ultimate web crippling loads per web $\left(P_{\mathrm{EXP}}\right)$ are given in Tables 1 and 2 for flange unfastened and fastened cases, respectively. Fig. 9(a) and (b) show the typical failure mode of web crippling of the specimens with web holes and without web holes for the flange unfastened and fastened to the bearing plate, respectively. Typical load-defection curves obtained from the specimens $142 \times 60 \times 13-$ t1.3-N100, both without and with web holes are shown in Figs. 10 and 11.

\section{Numerical Investigation}

\subsection{General}

The non-linear general purpose finite element program ABAQUS [16] was used to simulate the web crippling behaviour of the channel sections. The bearing plate, the load transfer block, the channel sections and the contact between the bearing plate and the channel section and load transfer block were modelled. The measured cross-section dimensions and the material properties from the tests were used. The channel sections of the model were based on the centreline dimensions of the cross-section. Specific modelling issues are described below.

\subsection{Geometry and material properties}

One-quarter of the test set-up was modelled, as shown in Fig. 5(b) and Fig. 6(b), Fig. 7(b) and Fig. 8(b). Contact surfaces are defined between the bearing plate and the cold-formed steel section. In addition, contact surfaces are defined between the load transfer block and cold-formed steel section.

The value of Young's modulus was $205 \mathrm{kN} / \mathrm{mm}^{2}$ and Poisson's ratio was 0.3. ABAQUS required the material stress-strain curve input as true stress-true strain. The stress-strain curves were directly obtained from the tensile tests and converted into true 
stress-strain curves using Equation 1 and Equation 2, as specified in the ABAQUS manual [16]:

$$
\begin{aligned}
& \sigma_{\text {true }}=\sigma(1+\varepsilon) \\
& \varepsilon_{\text {true }(p l)}=\ln (1+\varepsilon)-\frac{\sigma_{\text {true }}}{E}
\end{aligned}
$$

where $E$ is the Young's Modulus, $\sigma$ and $\varepsilon$ are the engineering stress and strain respectively in ABAQUS [16].

\subsection{Element type and mesh sensitivity}

Fig. 5(b), Fig. 6(b), Fig. 7(b) and Fig. 8(b) show details of a typical finite element mesh of the channel section, the bearing plate and load transfer block. A mesh sensitivity analysis was used to investigate the effect of different element sizes in the cross-section of the channel sections. Finite element mesh sizes were $5 \mathrm{~mm} \times 5 \mathrm{~mm}$ for the cold-formed steel channel sections and $8 \mathrm{~mm} \times 8 \mathrm{~mm}$ for the bearing plates and load transfer block.

From the mesh sensitivity analysis, due to the contact between the load transfer block and inside round corners that form the bend between the flange and web, it was found that at least fifteen elements were required for the corners between the flange and web. On the other hand, for the corners between the flange and lip of the section, only three elements were required. Finer mesh sizes were used around the web holes when the holes were modelled.

Cold-formed steel channel sections with and without web holes were modelled using S4R shell element. The S4R is a four-node double curved thin or thick shell element with reduced integration and finite membrane strains. It is mentioned in the ABAQUS Manual [16] that the S4R element is suitable for complex buckling behaviour. The S4R has six degrees of freedom per node and provides accurate solutions to most applications. The bearing plate and load transfer block were modelled using analytical rigid plates and C3D8R element, which is suitable for three-dimensional modelling of structures with 
plasticity, stress stiffening, large deflection, and large strain capabilities. The solid element is defined by eight nodes having three translational degrees of freedom at each node.

\subsection{Loading and boundary conditions}

The vertical load applied to the channel section through the bearing plate in the laboratory tests was modelled using displacement control. In the finite element model, a displacement in the vertical y direction was applied to the reference point of the analytical rigid plate that modelled the bearing plate. At the line of symmetry of the channel section, all nodes were restrained in the $\mathrm{z}$ direction and rotation about $\mathrm{x}$ and $\mathrm{y}$ axes. The nodes on symmetry surface of load transfer block were prevented from translational axes in the $\mathrm{x}$ direction and rotation about the $\mathrm{y}$ and $\mathrm{z}$ axes. The channel section specimens were tested in pairs, which were bolted to load transfer blocks at each end of the specimens through the web by a vertical row of M16 high tensile bolts.

In the shell element idealisation, cartesian connectors were used to simulate the bolts instead of physically modelling bolts and holes. "CONN3D2" connector elements were used to model the in-plane translational stiffness i.e. $y$ - and z-directions. The stiffness of the connectors element was $10 \mathrm{kN} / \mathrm{mm}$, which Lim et al. [18] suggestion would be suitable. In the $\mathrm{x}$ direction, the nodes were prevented from translating.

Contact between the bearing plate and the cold-formed steel section was modelled in ABAQUS using the contact pairs option. The two contact surfaces were not allowed to penetrate each other. No friction was modelled between the surfaces. In the flange fastened case, in addition to the contact modelled between the bearing plate and the coldformed steel sections, a connector between the flange and the bearing plate was modelled at the position of the bolt. 


\subsection{Verification of finite element model}

A comparison between the experimental results and the finite element results was carried out in order to verify and check the accuracy of the finite element model. The comparison of the web crippling strength per web obtained from the tests $\left(P_{\mathrm{EXP}}\right)$ and the finite element analysis $\left(P_{\mathrm{FEA}}\right)$ is shown in Table 4 and Table 5. The comparison of the load-deflection curves for the specimens $142 \times 60 \times 13-\mathrm{t} 1.3-\mathrm{N} 100$, without and with web holes, are shown in Fig. 10 and Fig 11, respectively. It is observed that good agreement has been achieved for both without web holes and with web holes cases.

For the unfastened to the bearing plate, the mean value of the ratio $P_{\mathrm{EXP}} / P_{\text {FEA }}$ is 1.02 and the corresponding coefficient of variation (COV) was 0.020. A maximum difference of 5\% and $9 \%$ was observed between the experimental and the numerical results for the specimens $142 \times 60 \times 13-\mathrm{t} 1.3-\mathrm{N} 150-\mathrm{A} 0.4-\mathrm{FR} \quad$ and $202 \times 65 \times 15-\mathrm{t} 1.4-\mathrm{N} 150-\mathrm{MA} 0.4-\mathrm{FR}$, respectively.

For the fastened to the bearing plate, the mean value of the ratio $P_{\mathrm{EXP}} / P_{\mathrm{FEA}}$ is 1.00 and the corresponding coefficient of variation $(\mathrm{COV})$ was 0.023 . A maximum difference of $6 \%$ and $4 \%$ was observed between the experimental and the numerical results for the specimens 302x90x18-t2.0-N100-A0.6-FX and 202x65x15-t1.4-N100-MA0-FX.

The web crippling failure mode observed from the tests has been also verified by the finite element model for the IOF loading condition, as shown in Figs. 5 to 8. It is shown that good agreement is achieved between the experimental and finite element results for both the web crippling strength and the failure mode.

\section{Conclusions}

Experimental and numerical investigations on the web crippling behaviour of coldformed steel lipped channel sections, with and without circular web holes, under the interior-one-flange (IOF) loading condition have been presented. A test programme on 
lipped channel sections with web holes located at the mid-depth of the web and centred beneath the bearing plate or with a horizontal clear distance to the near edge of bearing plate were considered. The channel specimens had the measured $0.2 \%$ proof stress (yield stress) of $457 \mathrm{MPa}, 464 \mathrm{MPa}$ and $479 \mathrm{MPa}$ for three different section sizes. The web slenderness values ranged from 109 to 157.8 . The diameter of the web hole was varied in order to investigate the influence of the web holes on the web crippling behaviour. Flange of the lipped channel sections were either fastened or unfastened to the bearing plate.

Finite element models have been developed and verified against the experimental results in term of web crippling failure loads and deformations. The finite element models provide a good prediction for web crippling strength of cold-formed lipped channel section with and without circular web holes. The verified finite element models can be used to carried out an extended study for developing reliable design recommendations for cold-formed steel sections.

\section{Acknowledgements}

The authors gratefully acknowledge the support given by Metsec Plc, UK, for providing the materials and to Mr Burns and Professor Jim Rhodes for arranging the materials provided. 


\section{References}

[1] J. Rhodes, D. Nash, An investigation of web crushing behaviour in thin-walled beams, Thin-Walled Structures, 32 (1998) 207-230.

[2] A. Uzzaman, J.B.P. Lim, D. Nash, J. Rhodes, B. Young, Web crippling behaviour of coldformed steel channel sections with offset web holes subjected to interior-two-flange loading, Thin-Walled Structures, 50 (2012) 76-86

[3] A. Uzzaman, J.B.P. Lim, D. Nash, J. Rhodes, B. Young, Effect of offset web holes on web crippling strength of cold-formed steel channel sections under end-two-flange loading condition, Thin-Walled Structures, 65 (2013) 34-48

[4] A. Uzzaman, J.B.P. Lim, D. Nash, J. Rhodes, B. Young, Cold-formed steel sections with web openings subjected to web crippling under two-flange loading conditions-part I: tests and finite element analysis, Thin-Walled Structures, 56 (2012) 38- 48.

[5] A. Uzzaman, J.B.P. Lim, D. Nash, J. Rhodes, B. Young, Cold-formed steel sections with web openings subjected to web crippling under two-flange loading conditions-part II: Parametric study and proposed design equations, Thin-Walled Structures, 56 (2012) $79-87$.

[6] W.W. Yu, C.S. Davis, Cold-formed steel members with perforated elements, Journal of the Structural Division, 99 (1973) 2061-2077.

[7] R.A. LaBoube, R.Schuster, Standard test method for determining the web crippling strength of cold-formed steel members, American Iron and Steel Institute, 2002.

[8] R.A. LaBoube, W.W. Yu, S.U. Deshmukh, C.A. Uphoff, Crippling Capacity of Web Elements with Openings, Journal of Structural Engineering, 125 (1999) 137-141. 
[9] NAS, North American Specification for the Design of Cold-Formed Steel Structural Members, American Iron and Steel Institute, AISI S100-2007, AISI Standard, 2007.

[10] K.S. Sivakumaran, K.M. Zielonka, Web crippling strength of thin-walled steel members with web opening, Thin-Walled Structures, 8 (1989) 295-319.

[11] F. Zhou, B. Young, Web crippling of aluminium tubes with perforated webs, Engineering Structures, 32 (2010) 1397-1410.

[12] P. Natario, N. Silvestre, D. Camotim, Computational modelling of flange crushing in cold-formed steel sections, Thin-Walled Structures, 84 (2014) 393-405.

[13] P. Keerthan, M. Mahendran, E. Steau, Experimental study of web crippling behaviour of hollow flange channel beams under two flange load cases, Thin-Walled Structures, 85 (2014) 207-219.

[14] Y. Chen, XX. Chen, CY. Wang, Experimental and finite element analysis research on cold-formed steel lipped channel beams under web crippling, Thin-walled Structures, 87 (2015) 41-52.

[15] Y. Chen, XX. Chen, CY. Wang, Aluminum tubular sections subjected to web crippling, Thin-Walled Structures, 90 (2015) 49-60.

[16] ABAQUS Analysis User's Manual-Version 6.13-1. ABAQUS Inc., USA, 2013. 
[17] EN, 10002-1: 2001. Tensile testing of metallic materials. Method of test at ambient temperature, British Standards Institution, 2001.

[18] J. B. P. Lim, D. A, Nethercot, Ultimate strength of bolted moment-connections between cold-formed steel members. Thin Walled Structures, 41 (2001) 1019-1039. 
Table 1 Measured specimen dimensions and experimental ultimate loads for flange unfastened case

\begin{tabular}{|c|c|c|c|c|c|c|c|c|c|c|}
\hline \multirow[t]{2}{*}{ Specimen } & Web & Flange & Lip & Thickness & Filet & \multicolumn{2}{|c|}{ Holes } & \multirow{2}{*}{$\begin{array}{l}\text { Length } \\
\text { L } \\
(\mathrm{mm})\end{array}$} & \multirow{2}{*}{$\begin{array}{l}\text { Experiment } \\
\text { result full } \\
\text { pair } \\
\mathrm{P}_{\mathrm{EXP}} \\
(\mathrm{kN})\end{array}$} & \multirow{2}{*}{$\begin{array}{c}\text { Exp. load } \\
\text { per Web } \\
\mathrm{P}_{\mathrm{EXP}} \\
(\mathrm{kN})\end{array}$} \\
\hline & $\begin{array}{c}\mathrm{d} \\
(\mathrm{mm})\end{array}$ & $\begin{array}{c}\mathrm{b}_{\mathrm{f}} \\
(\mathrm{mm})\end{array}$ & $\begin{array}{c}\mathrm{b}_{\mathrm{l}} \\
(\mathrm{mm})\end{array}$ & $\begin{array}{c}\mathrm{t} \\
(\mathrm{mm})\end{array}$ & $\begin{array}{c}\mathrm{r}_{\mathrm{i}} \\
(\mathrm{mm})\end{array}$ & $\begin{array}{l}\mathrm{a}_{\mathrm{LHS}} \\
(\mathrm{mm})\end{array}$ & $\begin{array}{l}\mathrm{a}_{\mathrm{RHS}} \\
(\mathrm{mm})\end{array}$ & & & \\
\hline 142x60x13-t1.3-N100-A0-FR & 141.82 & 60.63 & 13.66 & 1.27 & 4.80 & - & - & 720.0 & 21.56 & 10.78 \\
\hline $142 \times 60 \times 13-\mathrm{t} 1.3-\mathrm{N} 100-\mathrm{A} 0.6-\mathrm{FR}$ & 142.27 & 60.41 & 13.86 & 1.27 & 4.80 & 83.62 & 83.70 & 720.0 & 20.33 & 10.17 \\
\hline 142x60x13-t1.3-N100-MA0.6-FR & 142.31 & 59.94 & 13.97 & 1.28 & 4.80 & 83.64 & - & 720.0 & 20.64 & 10.32 \\
\hline $142 \times 60 \times 13-t 1.3-\mathrm{N} 120-\mathrm{A} 0-\mathrm{FR}$ & 142.24 & 60.37 & 13.90 & 1.27 & 4.80 & - & - & 740.0 & 23.27 & 11.64 \\
\hline $142 \times 60 \times 13-\mathrm{t} 1.3-\mathrm{N} 120-\mathrm{A} 0.6-\mathrm{FR}$ & 142.11 & 60.20 & 13.97 & 1.28 & 4.80 & 83.72 & 83.61 & 740.0 & 21.07 & 10.54 \\
\hline 142x60x13-t1.3-N120-MA0.6-FR & 142.42 & 60.20 & 13.60 & 1.27 & 4.80 & 83.73 & - & 740.0 & 21.14 & 10.57 \\
\hline $142 \times 60 \times 13-t 1.3-N 150-A 0-F R$ & 142.40 & 59.79 & 13.28 & 1.28 & 4.80 & - & - & 770.0 & 25.20 & 12.60 \\
\hline $142 \times 60 \times 13-\mathrm{t} 1.3-\mathrm{N} 150-\mathrm{A} 0.4-\mathrm{FR}$ & 142.17 & 59.88 & 12.95 & 1.28 & 4.80 & 55.04 & 55.04 & 770.0 & 25.20 & 12.49 \\
\hline 142x60x13-t1.3-N150-MA0.4-FR & 142.37 & 60.26 & 13.22 & 1.28 & 4.80 & 54.66 & 0.00 & 770.0 & 25.02 & 12.51 \\
\hline 202x65x15-t1.4-N100-A0-FR & 202.04 & 64.79 & 14.78 & 1.39 & 5.00 & - & - & 899.2 & 24.31 & 12.15 \\
\hline $202 \times 65 \times 15-\mathrm{t} 1.4-\mathrm{N} 100-\mathrm{A} 0.4-\mathrm{FR}$ & 202.03 & 64.86 & 14.98 & 1.39 & 5.00 & 79.20 & 79.30 & 900.0 & 23.40 & 11.70 \\
\hline 202x65x15-t1.4-N100-MA0.4-FR & 202.07 & 65.01 & 14.95 & 1.39 & 5.00 & 79.26 & - & 899.0 & 23.18 & 11.59 \\
\hline 202x65x15-t1.4-N100-MA0.6-FR & 202.11 & 65.45 & 14.39 & 1.39 & 5.00 & 119.07 & - & 900.0 & 21.62 & 10.81 \\
\hline 202x65x15-t1.4-N120-A0-FR & 202.00 & 65.00 & 14.73 & 1.39 & 5.00 & - & - & 920.0 & 25.96 & 12.98 \\
\hline $202 \times 65 \times 15-\mathrm{t} 1.4-\mathrm{N} 120-\mathrm{A} 0.4-\mathrm{FR}$ & 202.00 & 65.04 & 14.82 & 1.39 & 5.00 & 79.29 & 79.32 & 920.0 & 23.25 & 11.63 \\
\hline $202 \times 65 \times 15-\mathrm{t} 1.4-\mathrm{N} 120-\mathrm{A} 0.6-\mathrm{FR}$ & 202.66 & 65.35 & 14.57 & 1.38 & 5.00 & 119.13 & 119.30 & 920.0 & 22.32 & 11.16 \\
\hline 202x65x15-t1.4-N120-MA0.4-FR & 202.00 & 65.06 & 14.88 & 1.39 & 5.00 & 79.32 & - & 919.5 & 24.41 & 12.21 \\
\hline 202x65x15-t1.4-N120-MA0.6-FR & 202.26 & 65.39 & 14.50 & 1.39 & 5.00 & 119.39 & - & 920.0 & 21.90 & 10.95 \\
\hline 202x65x15-t1.4-N150-A0-FR & 202.01 & 65.04 & 14.98 & 1.45 & 5.00 & - & - & 950.0 & 29.01 & 14.51 \\
\hline $202 \times 65 \times 15-\mathrm{t} 1.4-\mathrm{N} 150-\mathrm{A} 0.4-\mathrm{FR}$ & 202.01 & 64.96 & 15.02 & 1.43 & 5.00 & 79.32 & 79.38 & 950.0 & 25.96 & 12.98 \\
\hline 202x65x15-t1.4-N150-MA0.4-FR & 202.00 & 65.09 & 15.00 & 1.39 & 5.00 & 79.32 & - & 949.5 & 26.46 & 13.23 \\
\hline $302 \times 90 \times 18-\mathrm{t} 2.0-\mathrm{N} 100-\mathrm{A} 0-\mathrm{FR}$ & 303.18 & 87.91 & 18.83 & 1.98 & 5.00 & - & - & 1200.0 & 49.14 & 24.57 \\
\hline $302 \times 90 \times 18-\mathrm{t} 2.0-\mathrm{N} 100-\mathrm{A} 0.6-\mathrm{FR}$ & 302.58 & 88.61 & 19.28 & 2.06 & 5.00 & 178.97 & 178.80 & 1196.7 & 43.78 & 21.89 \\
\hline
\end{tabular}




\begin{tabular}{|c|c|c|c|c|c|c|c|c|c|c|}
\hline $302 \times 90 \times 18-\mathrm{t} 2.0-\mathrm{N} 100-\mathrm{MA} 0.6-\mathrm{FR}$ & 303.05 & 88.20 & 18.99 & 1.98 & 5.00 & 179.00 & - & 1199.0 & 45.71 & 22.85 \\
\hline $302 \times 90 \times 18-t 2.0-\mathrm{N} 120-\mathrm{A} 0-\mathrm{FR}$ & 303.07 & 87.95 & 18.26 & 1.96 & 5.00 & - & - & 1221.0 & 50.31 & 25.16 \\
\hline 302x90x18-t2.0-N120-A0.6-FR & 303.05 & 88.03 & 18.32 & 2.06 & 5.00 & 178.93 & 179.04 & 1221.0 & 46.49 & 23.24 \\
\hline 302x90x18-t2.0-N120-MA0.6-FR & 303.03 & 87.99 & 18.30 & 1.98 & 5.00 & 179.00 & - & 1220.3 & 46.58 & 23.29 \\
\hline $302 \times 90 \times 18-\mathrm{t} 2.0-\mathrm{N} 150-\mathrm{A} 0-\mathrm{FR}$ & 303.03 & 88.54 & 18.97 & 1.99 & 5.00 & - & - & 1249.0 & 56.47 & 28.24 \\
\hline 302x90x18-t2.0-N150-A0.6-FR & 302.90 & 88.47 & 19.03 & 2.06 & 5.00 & 178.52 & 178.58 & 1248.3 & 48.80 & 24.40 \\
\hline 302x90x 18-t2.0-N150-MA0.6-FR & 303.63 & 88.25 & 19.11 & 1.99 & 5.00 & 178.66 & - & 1249.3 & 48.37 & 24.18 \\
\hline
\end{tabular}


Table 2 Measured specimen dimensions and experimental ultimate loads for flange fastened case

\begin{tabular}{|c|c|c|c|c|c|c|c|c|c|c|}
\hline \multirow[t]{2}{*}{ Specimen } & \multirow{2}{*}{$\begin{array}{c}\text { Web } \\
\mathrm{d} \\
(\mathrm{mm})\end{array}$} & \multirow{2}{*}{$\begin{array}{c}\text { Flange } \\
\mathrm{b}_{\mathrm{f}} \\
(\mathrm{mm})\end{array}$} & \multirow{2}{*}{$\begin{array}{c}\text { Lip } \\
\mathrm{b}_{1} \\
(\mathrm{~mm})\end{array}$} & \multirow{2}{*}{$\begin{array}{c}\text { Thickness } \\
\mathrm{t} \\
(\mathrm{mm})\end{array}$} & \multirow{2}{*}{$\begin{array}{c}\text { Filet } \\
\mathrm{r}_{\mathrm{i}} \\
(\mathrm{mm})\end{array}$} & \multicolumn{2}{|c|}{ Holes } & \multirow{2}{*}{$\begin{array}{l}\text { Length } \\
\text { L } \\
(\mathrm{mm})\end{array}$} & \multirow{2}{*}{$\begin{array}{c}\text { Experiment } \\
\text { result full } \\
\text { pair } \\
\mathrm{P}_{\mathrm{EXP}} \\
(\mathrm{kN})\end{array}$} & \multirow{2}{*}{$\begin{array}{c}\text { Exp. load } \\
\text { per Web } \\
P_{\text {EXP }} \\
(\mathrm{kN})\end{array}$} \\
\hline & & & & & & $\begin{array}{l}\mathrm{a}_{\mathrm{LHS}} \\
(\mathrm{mm})\end{array}$ & $\begin{array}{l}\mathrm{a}_{\mathrm{RHS}} \\
(\mathrm{mm})\end{array}$ & & & \\
\hline $142 \times 60 \times 13-t 1.3-N 100-A 0-F X$ & 142.49 & 60.33 & 13.79 & 1.29 & 4.80 & - & - & 720.0 & 22.28 & 11.14 \\
\hline $142 \times 60 \times 13-\mathrm{t} 1.3-\mathrm{N} 100-\mathrm{A} 0.6-\mathrm{FX}$ & 142.56 & 60.11 & 13.78 & 1.29 & 4.80 & 83.58 & 83.76 & 720.0 & 21.77 & 10.89 \\
\hline $142 \times 60 \times 13-\mathrm{t} 1.3-\mathrm{N} 100-\mathrm{MA} 0.6-\mathrm{FX}$ & 142.48 & 60.06 & 13.70 & 1.29 & 4.80 & 83.59 & - & 720.0 & 21.95 & 10.97 \\
\hline 142x60x13-t1.3-N120-A0-FX & 142.38 & 60.21 & 13.68 & 1.29 & 4.80 & - & - & 740.0 & 24.66 & 12.33 \\
\hline $142 \times 60 \times 13-\mathrm{t} 1.3-\mathrm{N} 120-\mathrm{A} 0.6-\mathrm{FX}$ & 142.26 & 60.22 & 13.67 & 1.29 & 4.80 & 83.80 & 83.76 & 740.0 & 23.94 & 11.97 \\
\hline 142x60x13-t1.3-N120-MA0.6-FX & 142.53 & 60.29 & 13.91 & 1.29 & 4.80 & 83.77 & - & 740.0 & 23.37 & 11.69 \\
\hline $142 \times 60 \times 13-\mathrm{t} 1.3-\mathrm{N} 150-\mathrm{A} 0-\mathrm{FX}$ & 142.18 & 60.12 & 13.19 & 1.28 & 4.80 & - & - & 770.0 & 26.95 & 13.48 \\
\hline $142 \times 60 \times 13-\mathrm{t} 1.3-\mathrm{N} 150-\mathrm{A} 0.4-\mathrm{FX}$ & 142.35 & 60.07 & 13.20 & 1.28 & 2.80 & 55.30 & 55.22 & 770.0 & 26.09 & 13.04 \\
\hline $142 \times 60 \times 13-\mathrm{t} 1.3-\mathrm{N} 150-\mathrm{MA} 0.4-\mathrm{FX}$ & 142.42 & 60.07 & 13.13 & 1.28 & 4.80 & 55.20 & - & 770.0 & 26.57 & 13.28 \\
\hline 202x65x15-t1.4-N100-A0-FX & 201.99 & 64.87 & 14.76 & 1.38 & 4.80 & - & - & 900.0 & 26.70 & 13.35 \\
\hline $202 \times 65 \times 15-\mathrm{t} 1.4-\mathrm{N} 100-\mathrm{A} 0.4-\mathrm{FX}$ & 202.01 & 64.96 & 14.76 & 1.37 & 4.80 & 79.36 & 79.35 & 900.0 & 24.84 & 12.42 \\
\hline $202 \times 65 \times 15-\mathrm{t} 1.4-\mathrm{N} 100-\mathrm{A} 0.6-\mathrm{FX}$ & 202.22 & 65.44 & 14.42 & 1.37 & 4.80 & 119.46 & 119.36 & 900.0 & 23.46 & 11.73 \\
\hline 202x65x15-t1.4-N100-MA0.4-FX & 202.11 & 64.92 & 14.99 & 1.37 & 4.80 & 79.30 & - & 899.8 & 25.21 & 12.60 \\
\hline $202 \times 65 \times 15-\mathrm{t} 1.4-\mathrm{N} 100-\mathrm{MA} 0.6-\mathrm{FX}$ & 201.79 & 65.68 & 14.64 & 1.37 & 4.80 & 119.45 & - & 899.8 & 24.36 & 12.18 \\
\hline 202x65x15-t1.4-N120-A0-FX & 202.05 & 64.99 & 14.82 & 1.41 & 4.80 & - & - & 920.0 & 29.21 & 14.60 \\
\hline $202 \times 65 \times 15-\mathrm{t} 1.4-\mathrm{N} 120-\mathrm{A} 0.4-\mathrm{FX}$ & 201.98 & 65.10 & 14.92 & 1.38 & 4.80 & 79.33 & 79.30 & 920.7 & 26.73 & 13.36 \\
\hline $202 \times 65 \times 15-\mathrm{t} 1.4-\mathrm{N} 120-\mathrm{A} 0.6-\mathrm{FX}$ & 201.76 & 65.40 & 14.62 & 1.39 & 4.80 & 119.44 & 119.55 & 920.0 & 25.96 & 12.98 \\
\hline $202 \times 65 \times 15-\mathrm{t} 1.4-\mathrm{N} 120-\mathrm{MA} 0.4-\mathrm{FX}$ & 202.00 & 65.16 & 15.02 & 1.39 & 4.80 & 79.36 & - & 920.0 & 27.89 & 13.94 \\
\hline $202 \times 65 \times 15-\mathrm{t} 1.4-\mathrm{N} 120-\mathrm{MA} 0.6-\mathrm{FX}$ & 202.42 & 65.36 & 14.40 & 1.39 & 4.80 & 119.41 & - & 920.0 & 24.88 & 12.44 \\
\hline 202x65x15-t1.4-N150-A0-FX & 202.00 & 64.93 & 15.00 & 1.41 & 4.80 & - & - & 950.0 & 32.27 & 16.14 \\
\hline $202 \times 65 \times 15-\mathrm{t} 1.4-\mathrm{N} 150-\mathrm{A} 0.4-\mathrm{FX}$ & 202.01 & 64.88 & 14.98 & 1.38 & 4.80 & 79.30 & 79.32 & 950.0 & 29.27 & 14.63 \\
\hline 202x65x15-t1.4-N150-MA0.4-FX & 202.02 & 64.88 & 14.79 & 1.38 & 4.80 & 79.32 & - & 949.5 & 29.92 & 14.96 \\
\hline $302 \times 90 \times 18-\mathrm{t} 2.0-\mathrm{N} 100-\mathrm{A} 0-\mathrm{FX}$ & 303.20 & 88.24 & 18.66 & 1.96 & 4.80 & - & - & 1199.0 & 50.52 & 25.26 \\
\hline $302 \times 90 \times 18-\mathrm{t} 2.0-\mathrm{N} 100-\mathrm{A} 0.6-\mathrm{FX}$ & 303.44 & 88.38 & 19.34 & 1.90 & 5.00 & 178.91 & 178.90 & 1201.3 & 45.89 & 22.95 \\
\hline
\end{tabular}




\begin{tabular}{|c|c|c|c|c|c|c|c|c|c|c|}
\hline $302 \times 90 \times 18-\mathrm{t} 2.0-\mathrm{N} 100-\mathrm{MA} 0.6-\mathrm{FX}$ & 303.45 & 88.57 & 19.26 & 1.91 & 5.00 & 178.42 & - & 1201.3 & 48.52 & 24.26 \\
\hline $302 \times 90 \times 18-t 2.0-\mathrm{N} 120-\mathrm{A} 0-\mathrm{FX}$ & 303.50 & 88.53 & 18.36 & 1.93 & 5.00 & - & - & 1219.0 & 52.80 & 26.40 \\
\hline 302x90x18-t2.0-N120-A0.6-FX & 303.28 & 88.79 & 18.55 & 1.90 & 5.00 & 178.65 & 178.81 & 1219.0 & 47.48 & 23.74 \\
\hline $302 \times 90 \times 18-\mathrm{t} 2.0-\mathrm{N} 120-\mathrm{A} 0.6-\mathrm{FX}$ & 303.02 & 88.77 & 18.48 & 1.90 & 5.00 & 178.69 & - & 1220.3 & 48.36 & 24.18 \\
\hline $302 \times 90 \times 18-\mathrm{t} 2.0-\mathrm{N} 150-\mathrm{A} 0-\mathrm{FX}$ & 303.85 & 88.71 & 18.41 & 1.90 & 5.00 & - & - & 1248.3 & 56.26 & 28.13 \\
\hline $302 \times 90 \times 18-\mathrm{t} 2.0-\mathrm{N} 150-\mathrm{A} 0.6-\mathrm{FX}$ & 303.19 & 88.32 & 19.09 & 1.96 & 5.00 & 178.14 & 178.76 & 1251.0 & 51.32 & 25.66 \\
\hline 302x90x 18-t2.0-N150-MA0.6-FX & 303.08 & 88.42 & 19.06 & 1.90 & 5.00 & 178.40 & - & 1249.0 & 49.78 & 24.89 \\
\hline
\end{tabular}

Table 3 Measured material properties of specimens

\begin{tabular}{lll}
\hline Section & $\sigma_{0.2}(\mathrm{MPa})$ & $\sigma_{u}(\mathrm{MPa})$ \\
\hline $142 \times 60 \times 13 \times 1.3$ & 457 & 496 \\
$202 \times 65 \times 15 \times 1.4$ & 464 & 566 \\
$302 \times 88 \times 18 \times 2.0$ & 479 & 575 \\
\hline
\end{tabular}


Table 4 Comparison of web crippling strength predicted from finite element analysis with experiment results for flange unfastened case

\begin{tabular}{|c|c|c|c|c|c|}
\hline \multirow[t]{2}{*}{ Specimen } & $\begin{array}{c}\text { Web } \\
\text { slenderness }\end{array}$ & $\begin{array}{l}\text { Hole } \\
\text { diameter } \\
\text { ratio }\end{array}$ & $\begin{array}{l}\text { Exp.load } \\
\text { per web }\end{array}$ & $\begin{array}{c}\text { Web crippling strength } \\
\text { per web predicted from } \\
\text { FEA }\end{array}$ & Comparison \\
\hline & $(\mathrm{h} / \mathrm{t})$ & $(\mathrm{a} / \mathrm{h})$ & $\mathrm{P}_{\mathrm{EXP}}(\mathrm{kN})$ & $\mathrm{P}_{\mathrm{FEA}}(\mathrm{kN})$ & $\mathrm{P}_{\mathrm{EXP}} / \mathrm{P}_{\mathrm{FEA}}$ \\
\hline 142x60x13-t1.3-N100-A0-FR & 109.67 & - & 10.78 & 10.69 & 1.01 \\
\hline $142 \times 60 \times 13-\mathrm{t} 1.3-\mathrm{N} 100-\mathrm{A} 0.6-\mathrm{FR}$ & 110.03 & 0.60 & 10.17 & 9.98 & 1.02 \\
\hline 142x60x13-t1.3-N100-MA0.6-FR & 109.18 & 0.60 & 10.32 & 10.19 & 1.01 \\
\hline 142x60x13-t1.3-N120-A0-FR & 110.00 & - & 11.64 & 11.52 & 1.01 \\
\hline 142x60x13-t1.3-N120-A0.6-FR & 109.02 & 0.60 & 10.54 & 10.17 & 1.04 \\
\hline 142x60x13-t1.3-N120-MA0.6-FR & 110.14 & 0.60 & 10.57 & 10.43 & 1.01 \\
\hline 142x60x13-t1.3-N150-A0-FR & 109.25 & - & 12.60 & 12.44 & 1.01 \\
\hline 142x60x13-t1.3-N150-A0.4-FR & 109.07 & 0.39 & 12.49 & 11.90 & 1.05 \\
\hline 142x60x13-t1.3-N150-MA0.4-FR & 109.23 & 0.39 & 12.51 & 11.87 & 1.05 \\
\hline 202x65x15-t1.4-N100-A0-FR & 143.35 & - & 12.15 & 12.17 & 1.00 \\
\hline 202x65x15-t1.4-N100-A0.4-FR & 143.35 & 0.40 & 11.70 & 11.41 & 1.02 \\
\hline 202x65x15-t1.4-N100-MA0.4-FR & 143.37 & 0.40 & 11.59 & 11.75 & 0.99 \\
\hline $202 \times 65 \times 15-\mathrm{t} 1.4-\mathrm{N} 100-\mathrm{MA} 0.6-\mathrm{FR}$ & 143.40 & 0.60 & 10.81 & 10.50 & 1.03 \\
\hline 202x65x15-t1.4-N120-A0-FR & 143.33 & - & 12.98 & 12.58 & 1.03 \\
\hline 202x65x15-t1.4-N120-A0.4-FR & 143.33 & 0.40 & 11.63 & 11.65 & 1.00 \\
\hline 202x65x15-t1.4-N120-A0.6-FR & 137.76 & 0.60 & 11.16 & 10.89 & 1.03 \\
\hline 202x65x15-t1.4-N120-MA0.4-FR & 143.32 & 0.40 & 12.21 & 11.95 & 1.02 \\
\hline 202x65x15-t1.4-N120-MA0.6-FR & 143.51 & 0.60 & 10.95 & 10.66 & 1.03 \\
\hline 202x65x15-t1.4-N150-A0-FR & 137.31 & - & 14.51 & 14.24 & 1.02 \\
\hline 202x65x15-t1.4-N150-A0.4-FR & 139.27 & 0.40 & 12.98 & 12.68 & 1.02 \\
\hline 202x65x15-t1.4-N150-MA0.4-FR & 143.32 & 0.40 & 13.23 & 12.18 & 1.09 \\
\hline $302 \times 90 \times 18-\mathrm{t} 2.0-\mathrm{N} 100-\mathrm{A} 0-\mathrm{FR}$ & 151.12 & - & 24.57 & 24.34 & 1.01 \\
\hline $302 \times 90 \times 18-\mathrm{t} 2.0-\mathrm{N} 100-\mathrm{A} 0.6-\mathrm{FR}$ & 144.88 & 0.60 & 21.89 & 21.82 & 1.00 \\
\hline 302x90x18-t2.0-N100-MA0.6-FR & 151.06 & 0.60 & 22.85 & 22.44 & 1.02 \\
\hline $302 \times 90 \times 18-\mathrm{t} 2.0-\mathrm{N} 120-\mathrm{A} 0-\mathrm{FR}$ & 152.63 & - & 25.16 & 25.50 & 0.99 \\
\hline $302 \times 90 \times 18-\mathrm{t} 2.0-\mathrm{N} 120-\mathrm{A} 0.6-\mathrm{FR}$ & 145.11 & 0.60 & 23.24 & 22.30 & 1.04 \\
\hline
\end{tabular}




\begin{tabular}{lccccc}
$302 \times 90 \times 18-t 2.0-N 120-M A 0.6-F R$ & 151.05 & 0.60 & 23.29 & 22.68 & 1.03 \\
$302 \times 90 \times 18-t 2.0-N 150-A 0-F R$ & 150.28 & - & 28.24 & 27.99 & 1.01 \\
$302 \times 90 \times 18-t 2.0-N 150-A 0.6-F R$ & 145.04 & 0.60 & 24.40 & 23.42 & 1.04 \\
$302 \times 90 \times 18-t 2.0-N 150-M A 0.6-F R$ & 150.58 & 0.60 & 24.18 & 23.57 & 1.03 \\
\hline Mean & & & & 1.02 \\
COV & & & & 0.020 \\
\hline
\end{tabular}


Table 5 Comparison of web crippling strength predicted from finite element analysis with experiment results for flange fastened case

\begin{tabular}{|c|c|c|c|c|c|}
\hline Specimen & $\begin{array}{c}\text { Web } \\
\text { slenderness } \\
(\mathrm{h} / \mathrm{t})\end{array}$ & $\begin{array}{l}\text { Hole } \\
\text { diameter } \\
\text { ratio } \\
(\mathrm{a} / \mathrm{h})\end{array}$ & $\begin{array}{l}\text { Exp.load } \\
\text { per web } \\
\mathrm{P}_{\mathrm{EXP}}(\mathrm{kN})\end{array}$ & $\begin{array}{c}\text { Web crippling strength } \\
\text { per web predicted from } \\
\text { FEA } \\
P_{\mathrm{FEA}}(\mathrm{kN})\end{array}$ & $\begin{array}{l}\text { Comparison } \\
\mathrm{P}_{\mathrm{EXP}} / \mathrm{P}_{\mathrm{FEA}}\end{array}$ \\
\hline 142x60x13-t1.3-N100-A0-FX & 108.45 & - & 11.24 & 11.39 & 0.99 \\
\hline 142x60x13-t1.3-N100-A0.6-FX & 108.51 & 0.60 & 10.89 & 10.78 & 1.01 \\
\hline 142x60x13-t1.3-N100-MA0.6-FX & 108.45 & 0.60 & 10.97 & 10.90 & 1.01 \\
\hline 142x60x13-t1.3-N120-A0-FX & 108.37 & - & 12.24 & 12.38 & 0.99 \\
\hline 142x60x13-t1.3-N120-A0.6-FX & 108.28 & 0.60 & 11.97 & 11.53 & 1.04 \\
\hline 142x60x13-t1.3-N120-MA0.6-FX & 108.49 & 0.60 & 11.69 & 11.44 & 1.02 \\
\hline 142x60x13-t1.3-N150-A0-FX & 109.08 & - & 13.48 & 13.42 & 1.00 \\
\hline $142 \times 60 \times 13-\mathrm{t} 1.3-\mathrm{N} 150-\mathrm{A} 0.4-\mathrm{FX}$ & 109.21 & 0.40 & 13.04 & 13.30 & 0.98 \\
\hline 142x60x13-t1.3-N150-MA0.4-FX & 109.26 & 0.39 & 13.28 & 13.04 & 1.02 \\
\hline 202x65x15-t1.4-N100-A0-FX & 145.44 & - & 13.35 & 12.78 & 1.04 \\
\hline $202 \times 65 \times 15-\mathrm{t} 1.4-\mathrm{N} 100-\mathrm{A} 0.4-\mathrm{FX}$ & 145.45 & 0.40 & 12.42 & 12.67 & 0.98 \\
\hline $202 \times 65 \times 15-\mathrm{t} 1.4-\mathrm{N} 100-\mathrm{A} 0.6-\mathrm{FX}$ & 145.61 & 0.60 & 11.73 & 11.61 & 1.01 \\
\hline 202x65x15-t1.4-N100-MA0.4-FX & 145.53 & 0.40 & 12.60 & 12.64 & 1.00 \\
\hline 202x65x15-t1.4-N100-MA0.6-FX & 145.29 & 0.60 & 12.18 & 12.33 & 0.99 \\
\hline 202x65x15-t1.4-N120-A0-FX & 141.30 & - & 14.60 & 14.43 & 1.01 \\
\hline $202 \times 65 \times 15-\mathrm{t} 1.4-\mathrm{N} 120-\mathrm{A} 0.4-\mathrm{FX}$ & 144.36 & 0.40 & 13.36 & 13.69 & 0.98 \\
\hline 202x65x15-t1.4-N120-A0.6-FX & 143.15 & 0.60 & 12.98 & 12.57 & 1.03 \\
\hline 202x65x15-t1.4-N120-MA0.4-FX & 143.33 & 0.40 & 13.94 & 14.16 & 0.98 \\
\hline $202 \times 65 \times 15-\mathrm{t} 1.4-\mathrm{N} 120-\mathrm{MA} 0.6-\mathrm{FX}$ & 143.63 & 0.60 & 12.44 & 12.97 & 0.96 \\
\hline 202x65x15-t1.4-N150-A0-FX & 141.26 & - & 16.14 & 15.75 & 1.02 \\
\hline $202 \times 65 \times 15-\mathrm{t} 1.4-\mathrm{N} 150-\mathrm{A} 0.4-\mathrm{FX}$ & 144.38 & 0.40 & 14.63 & 14.83 & 0.99 \\
\hline 202x65x15-t1.4-N150-MA0.4-FX & 144.39 & 0.40 & 14.96 & 14.98 & 1.00 \\
\hline $302 \times 90 \times 18-\mathrm{t} 2.0-\mathrm{N} 100-\mathrm{A} 0-\mathrm{FX}$ & 152.70 & - & 25.26 & 25.16 & 1.00 \\
\hline $302 \times 90 \times 18-\mathrm{t} 2.0-\mathrm{N} 100-\mathrm{A} 0.6-\mathrm{FX}$ & 157.71 & 0.60 & 22.95 & 24.47 & 0.94 \\
\hline $302 \times 90 \times 18-t 2.0-\mathrm{N} 100-\mathrm{MA} 0.6-\mathrm{FX}$ & 156.87 & 0.60 & 24.26 & 24.21 & 1.00 \\
\hline $302 \times 90 \times 18-\mathrm{t} 2.0-\mathrm{N} 120-\mathrm{A} 0-\mathrm{FX}$ & 155.25 & - & 26.40 & 26.34 & 1.00 \\
\hline
\end{tabular}




\begin{tabular}{lccccc}
$302 \times 90 \times 18-t 2.0-N 120-A 0.6-F X$ & 157.62 & 0.60 & 23.74 & 23.54 & 1.01 \\
$302 \times 90 \times 18-t 2.0-N 120-M A 0.6-F X$ & 157.48 & 0.60 & 24.18 & 24.91 & 0.97 \\
$302 \times 90 \times 18-t 2.0-N 150-A 0-F X$ & 157.92 & - & 28.13 & 28.09 & 1.00 \\
$302 \times 90 \times 18-t 2.0-N 150-A 0.6-F X$ & 152.69 & 0.60 & 25.66 & 25.60 & 1.00 \\
$302 \times 90 \times 18-t 2.0-N 150-M A 0.6-F X$ & 157.52 & 0.60 & 24.89 & 24.70 & 1.01 \\
\hline Mean & & & & 1.00 \\
COV & & & & 0.023 \\
\hline
\end{tabular}




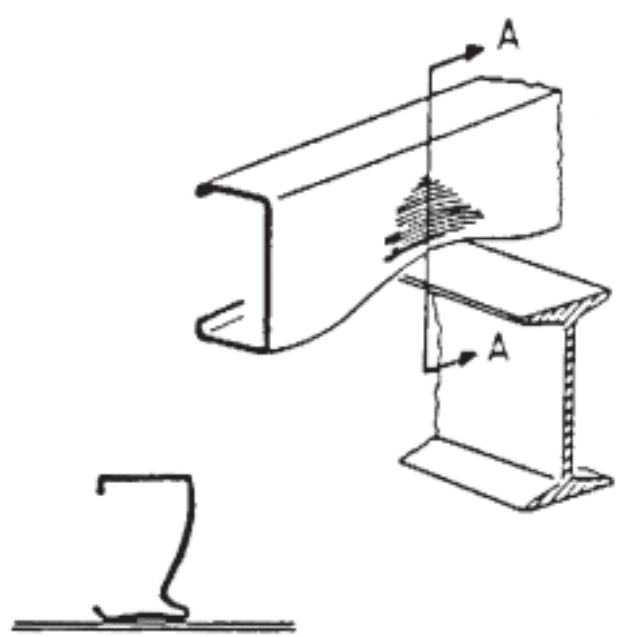

Section A-A

Fig.1 Web crippling at a support point [1] 


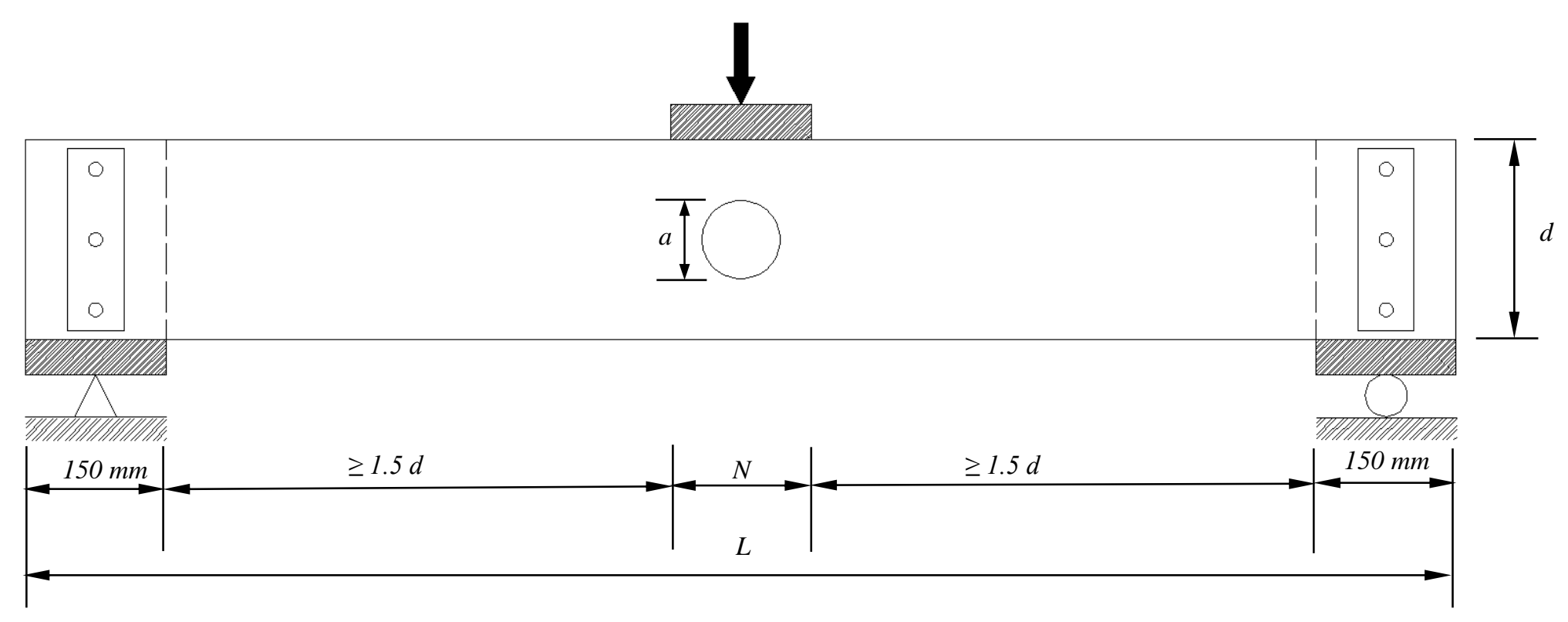

(a) With holes centred under bearing plate 


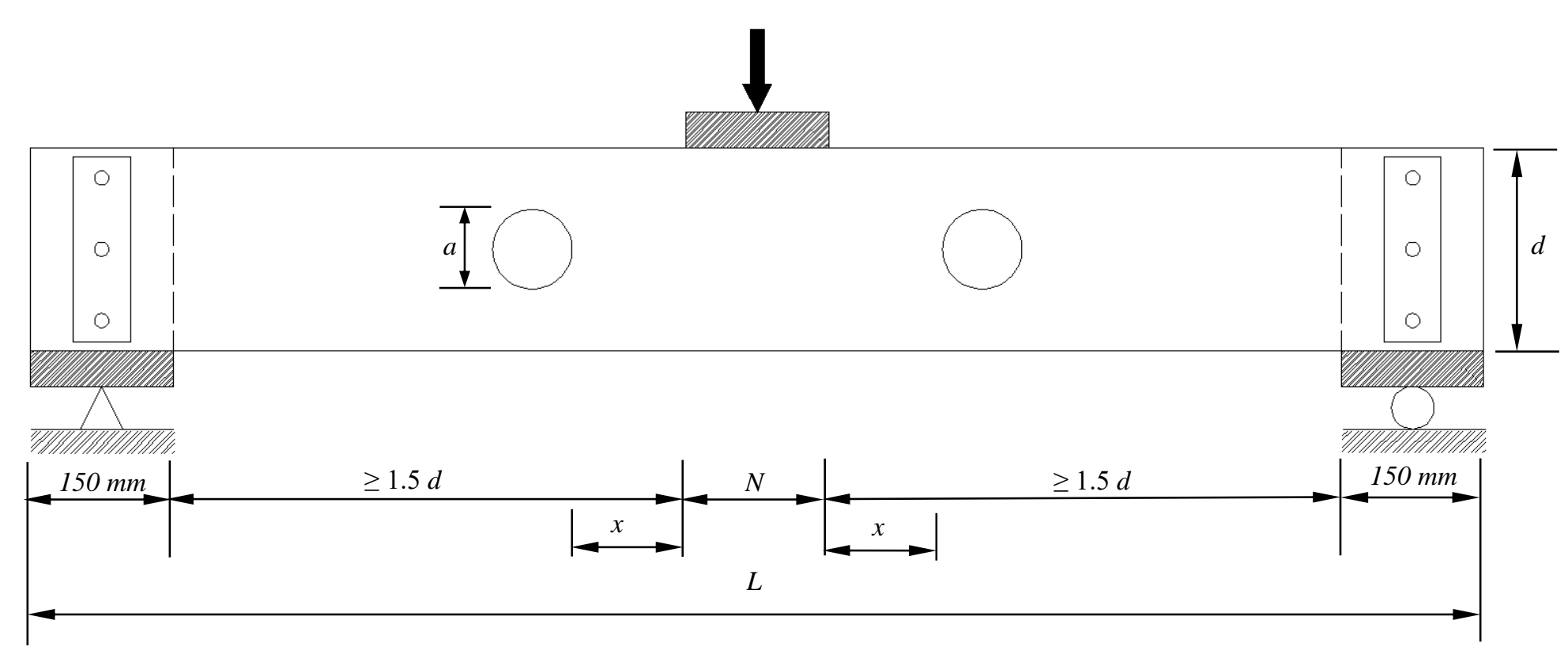

(b) With holes offset from bearing plate

Fig.2 Interior-one-flange loading condition 


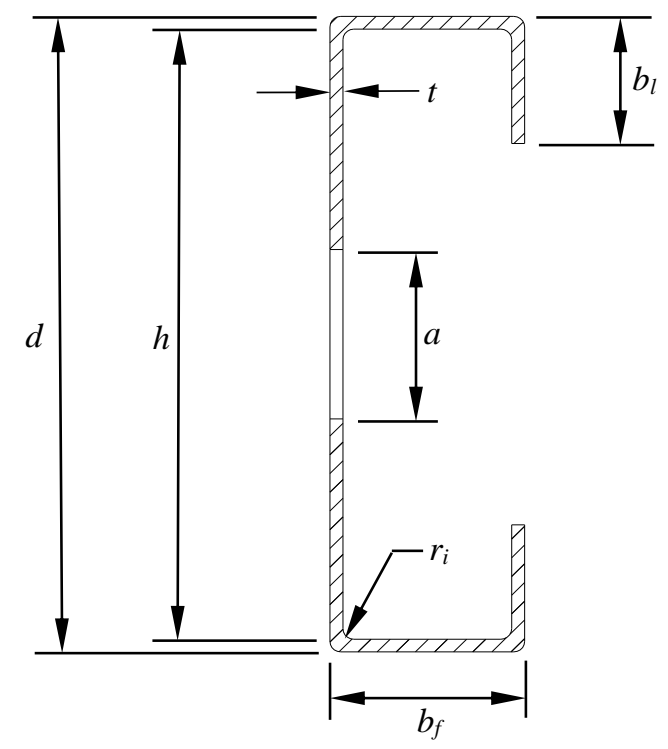

Fig.3 Definition of symbols 


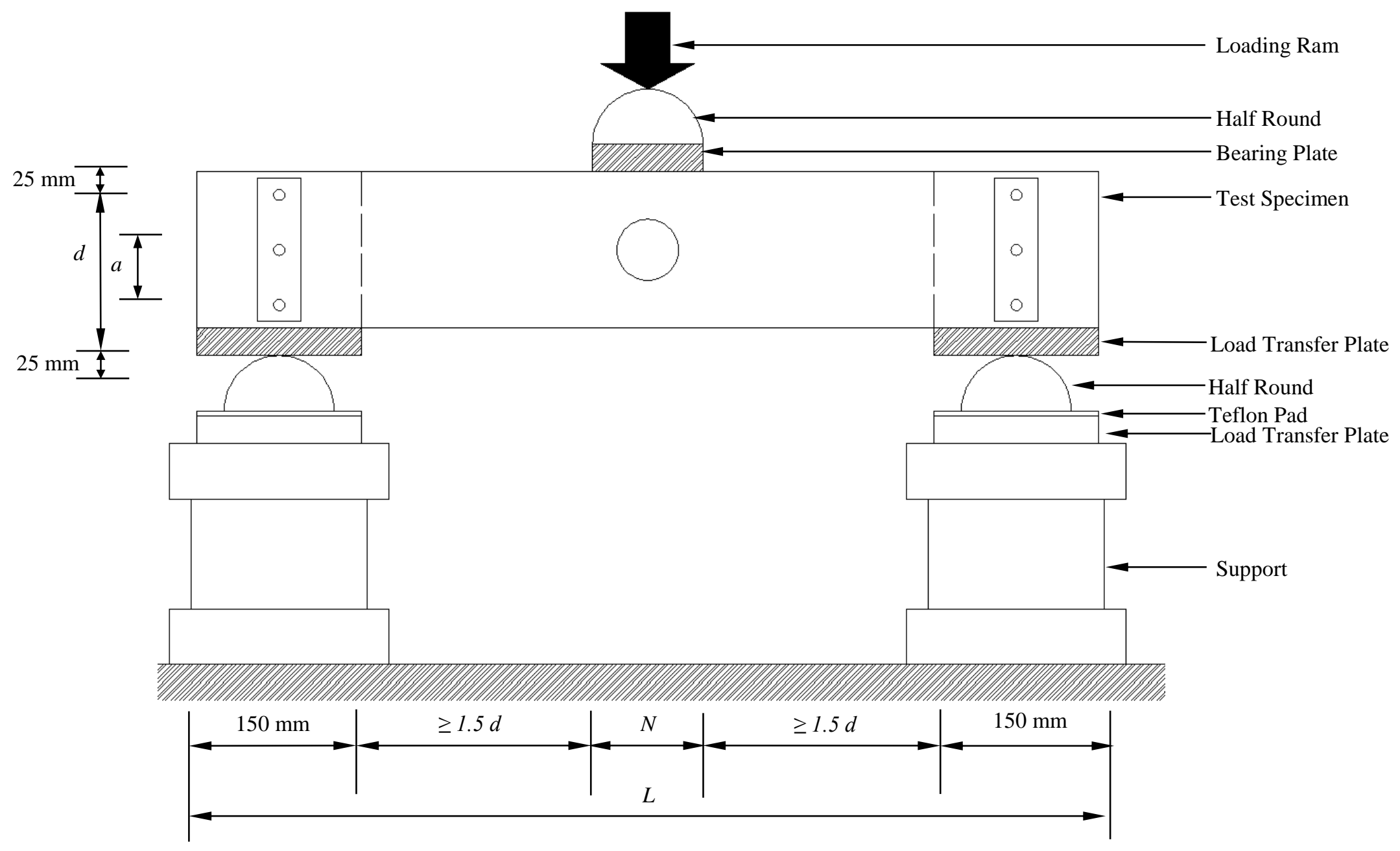

(a) Front view of with hole centred under bearing plate 


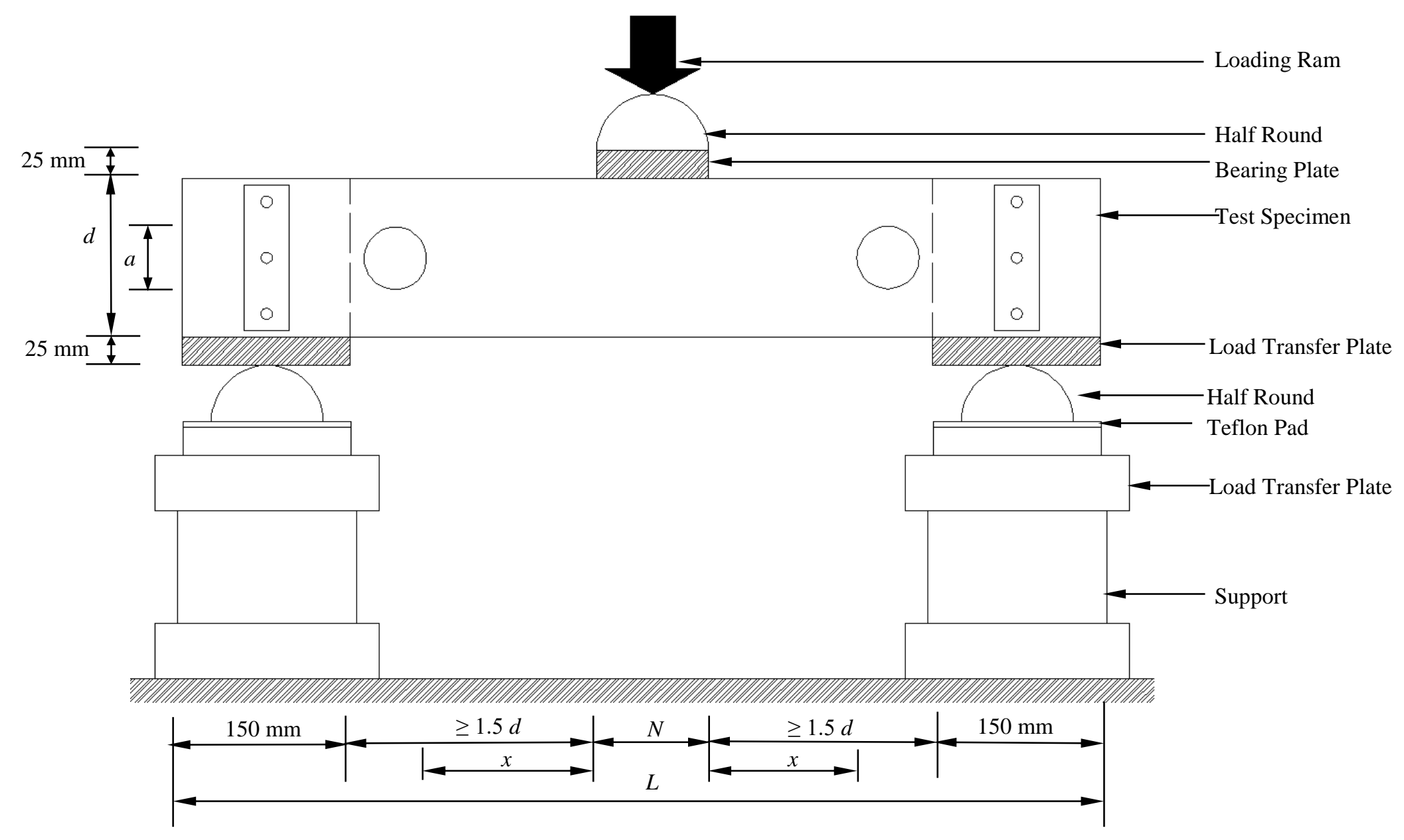

(b) Front view of with a horizontal clear distance to near edge of bearing plate 


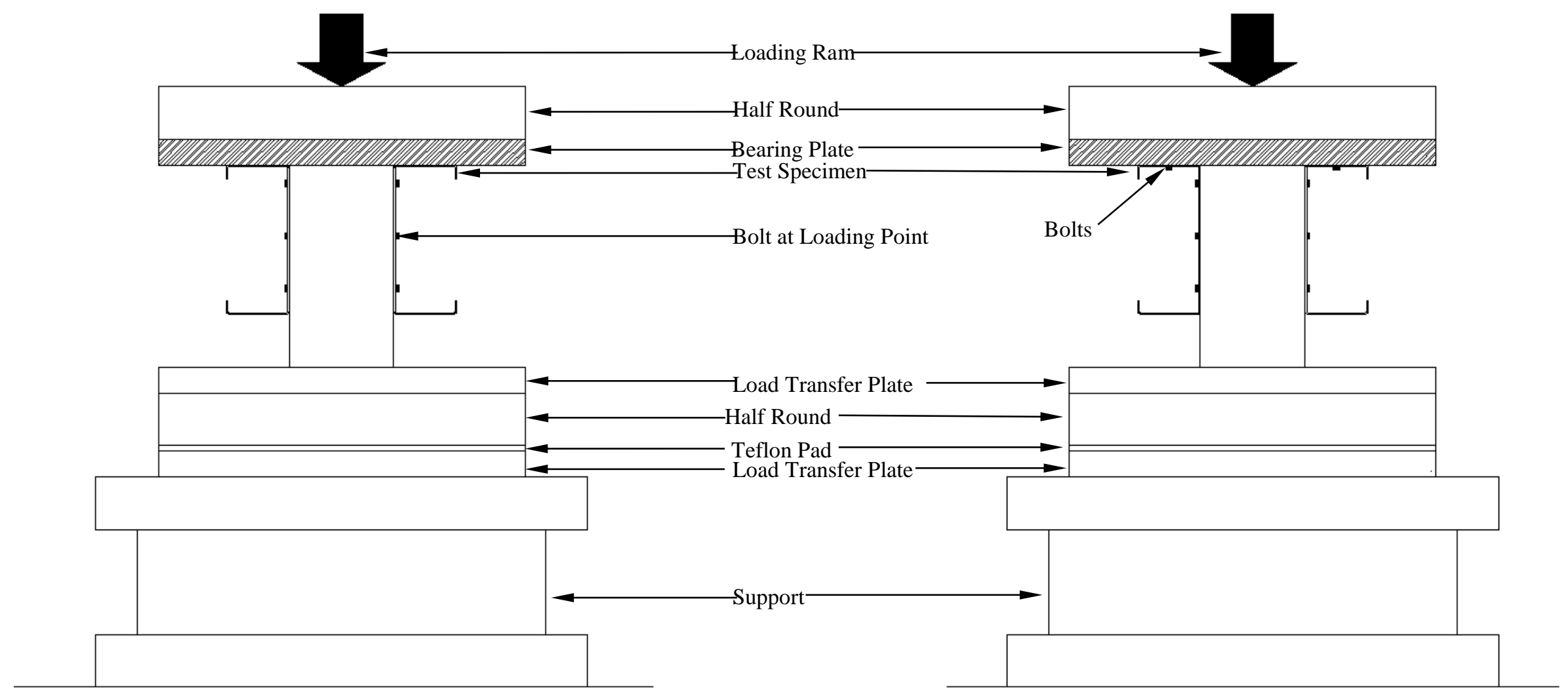

(c) End View (Unfastened flange)

(d) End View (Fastened flange)

Fig.4 Schematic view of test set-up 


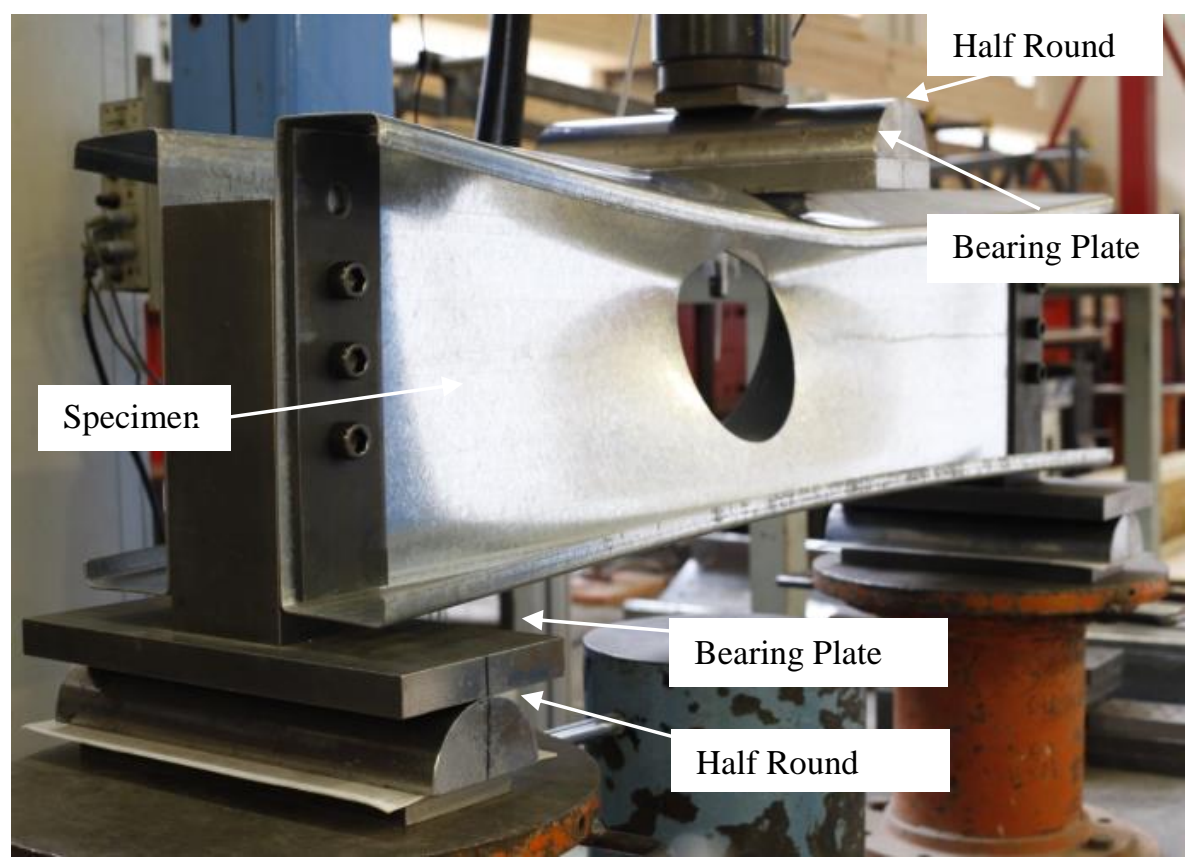

(a) Experimental

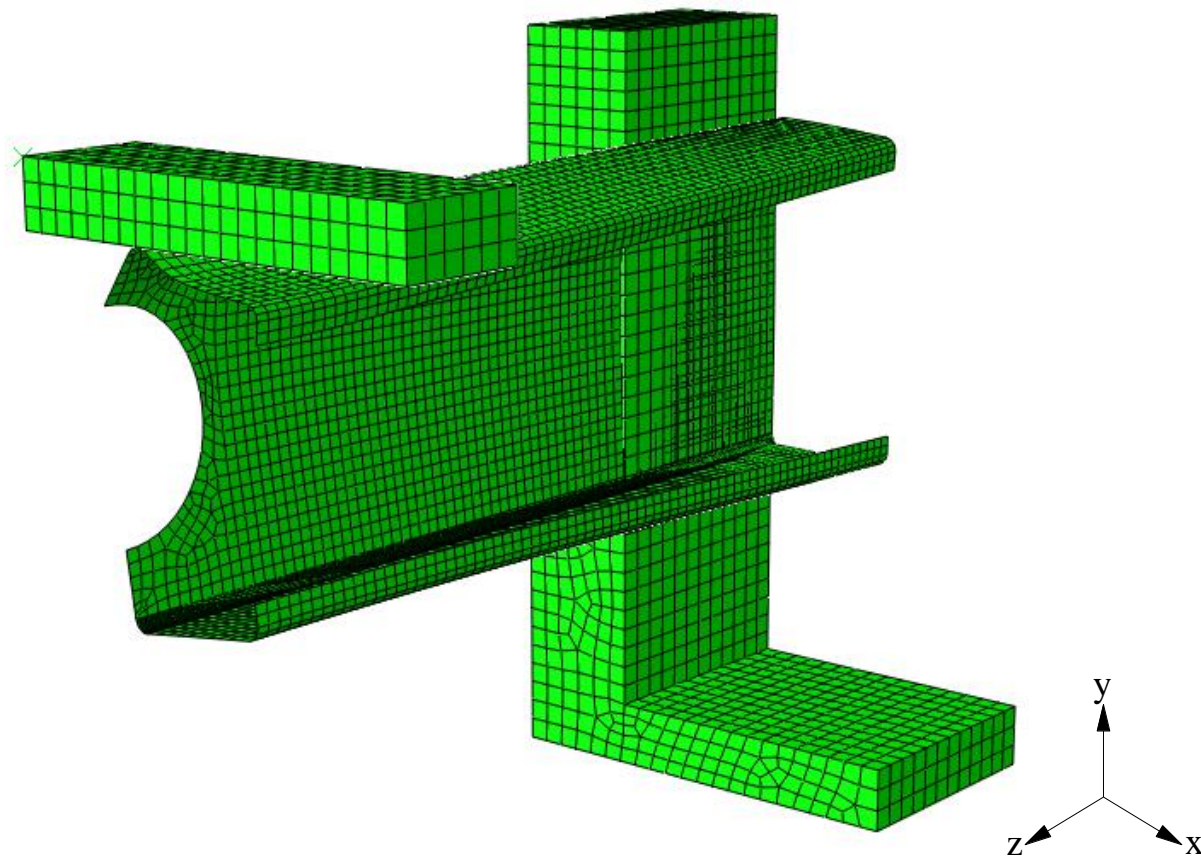

(b) FEA

Fig.5 Comparison of experiment and finite element analysis for centred hole where flange unfastened to bearing plate 

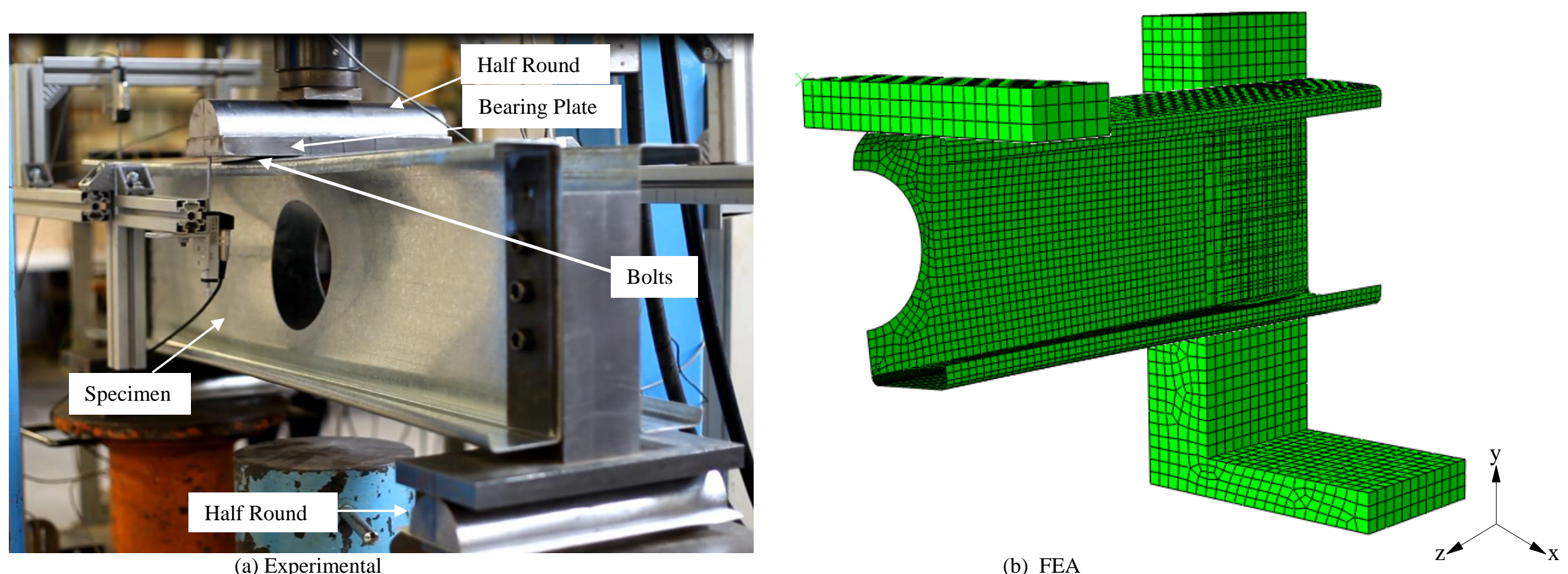

Fig.6 Comparison of experiment and finite element analysis for centred hole where flange fastened to bearing plate 


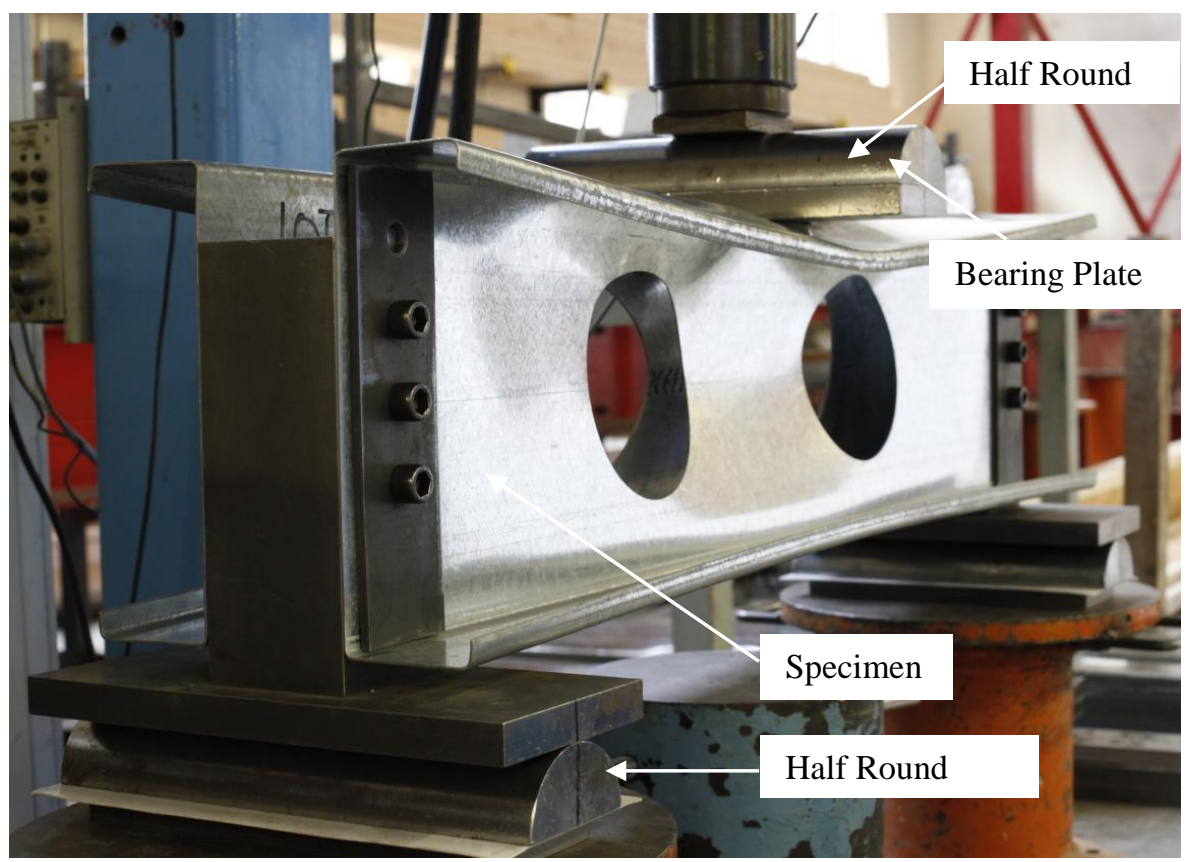

(a) Experimental

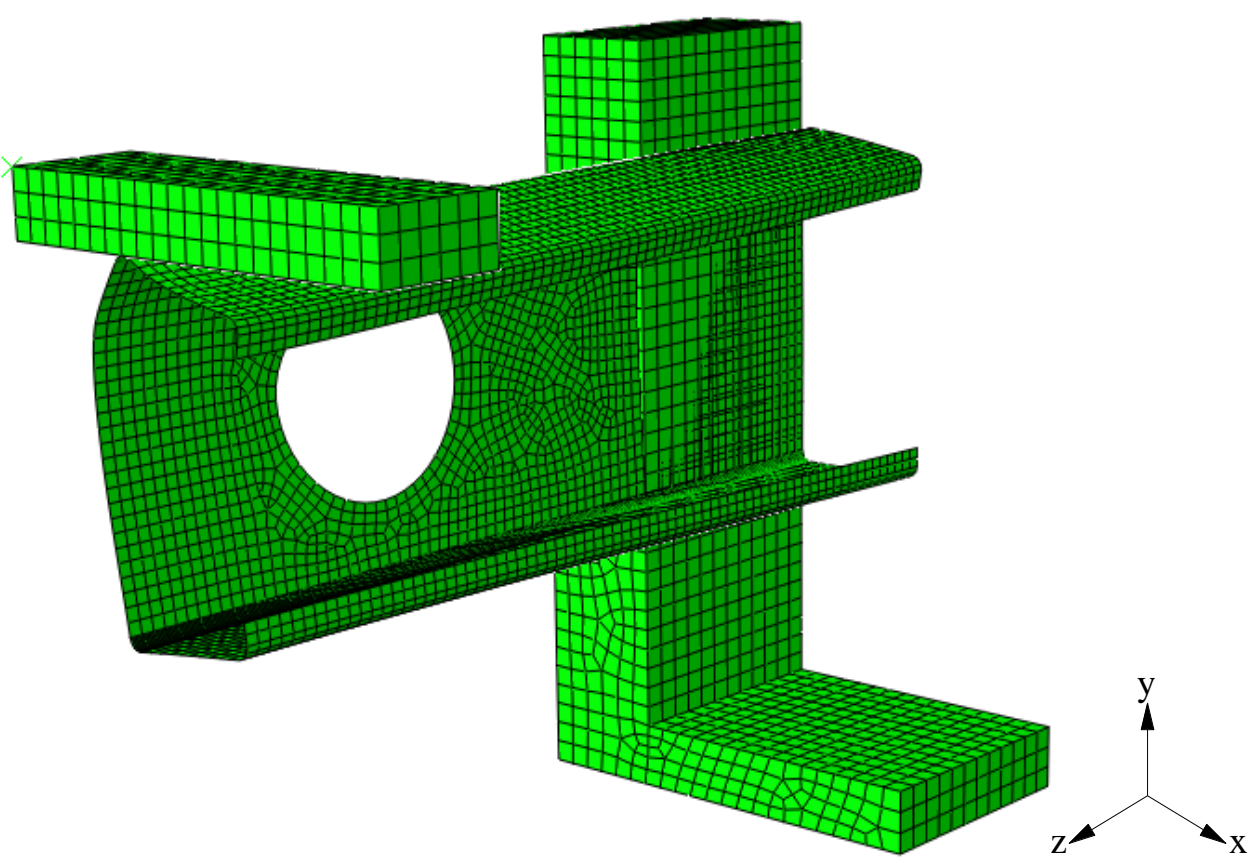

(b) FEA

Fig.7 Comparison of experiment and finite element analysis for offset hole where flange unfastened to bearing plate 

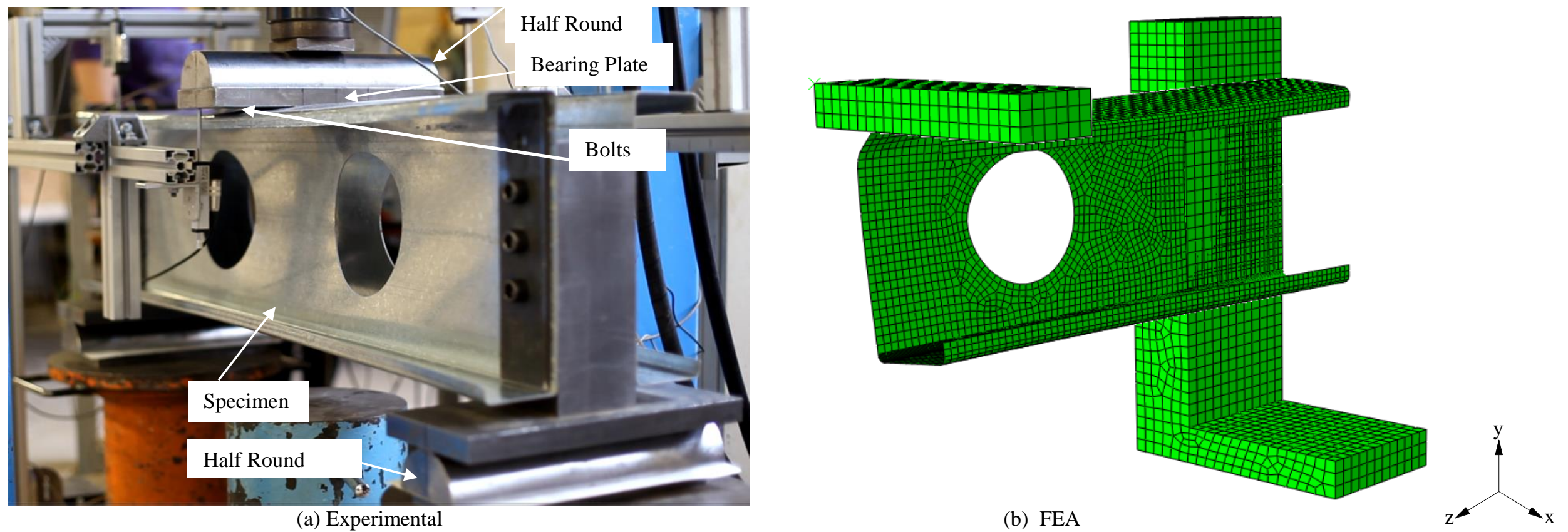

(a) Experimental

(b) FEA

Fig.8 Comparison of experiment and finite element analysis for offset hole where flange fastened to bearing plate 


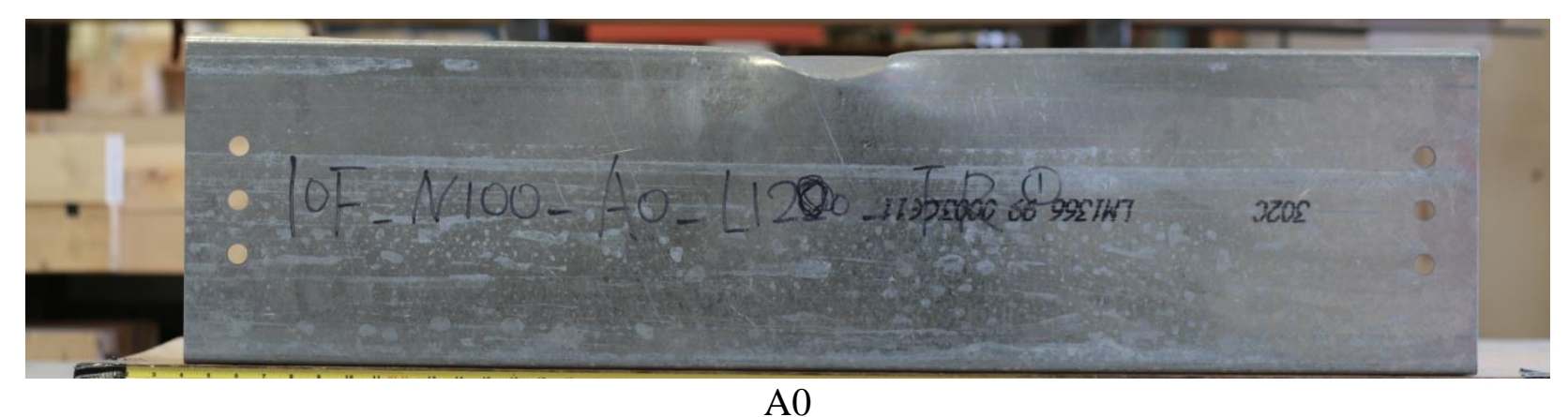

A0
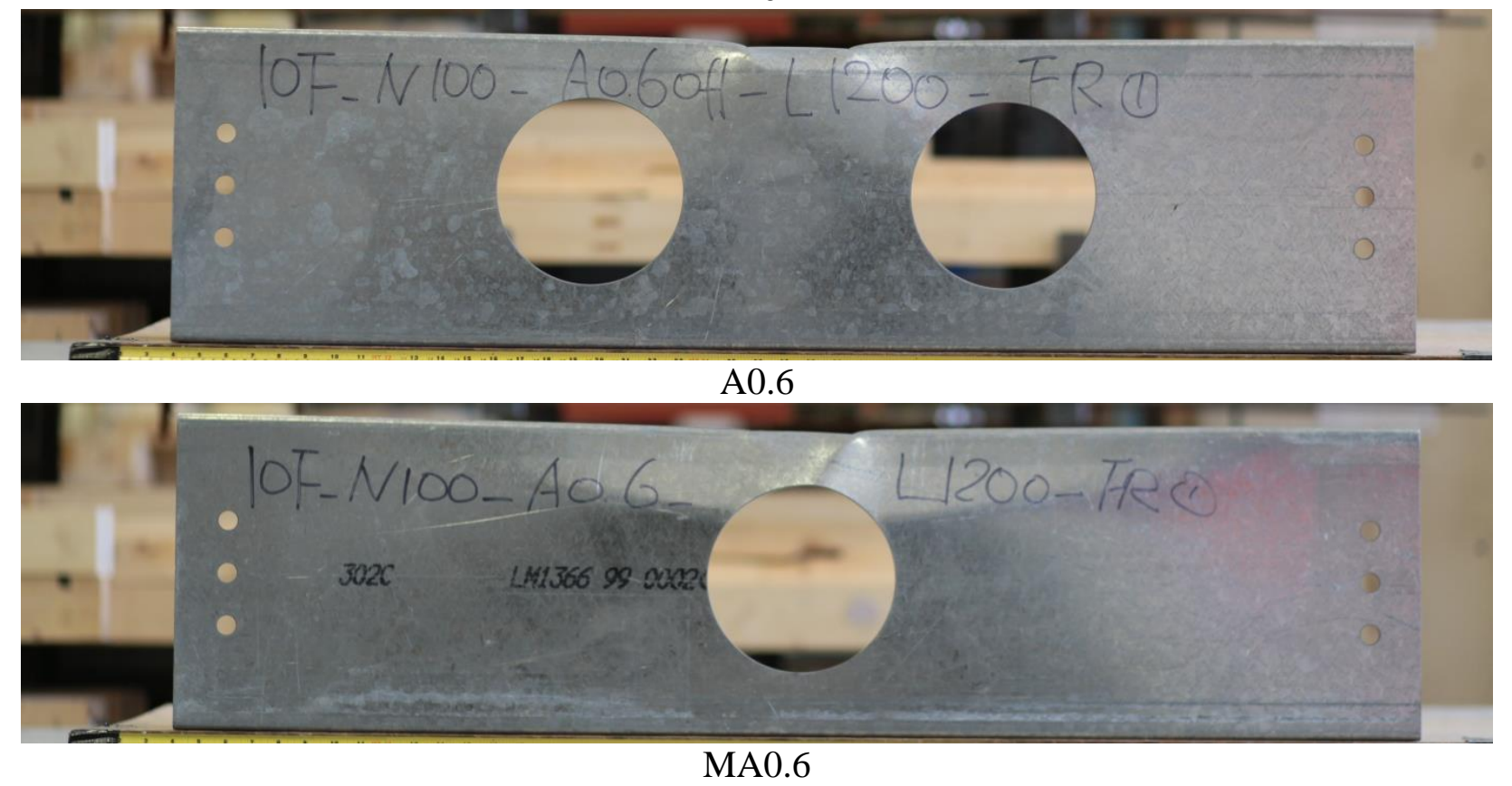

(a) Specimen for the flange unfastened case 


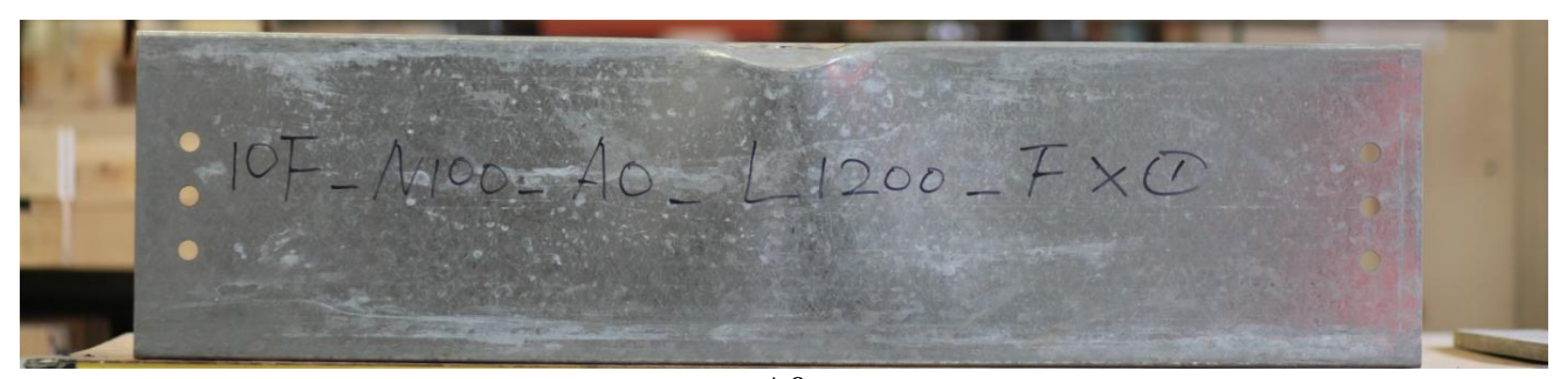

A0

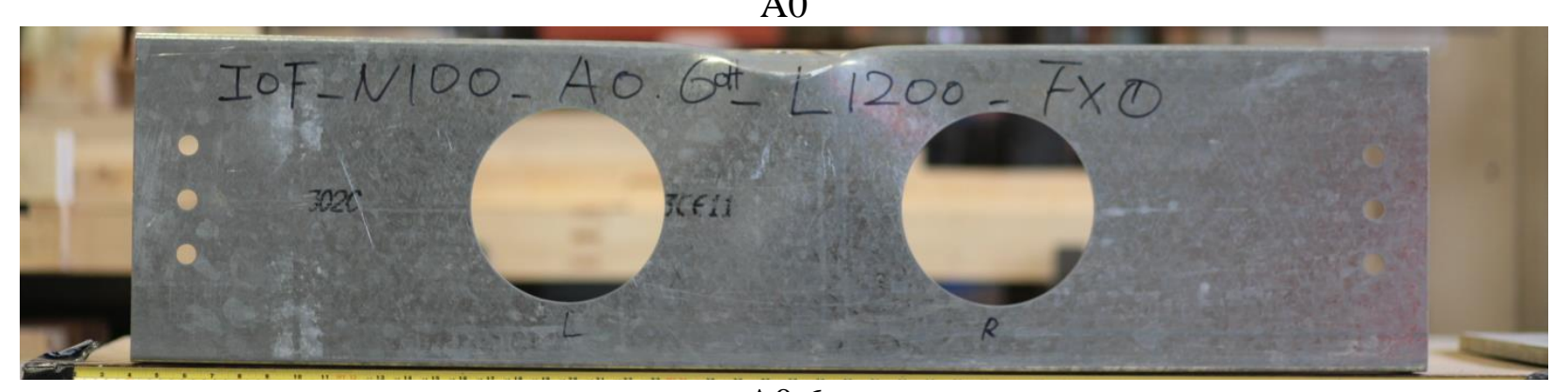

A0.6

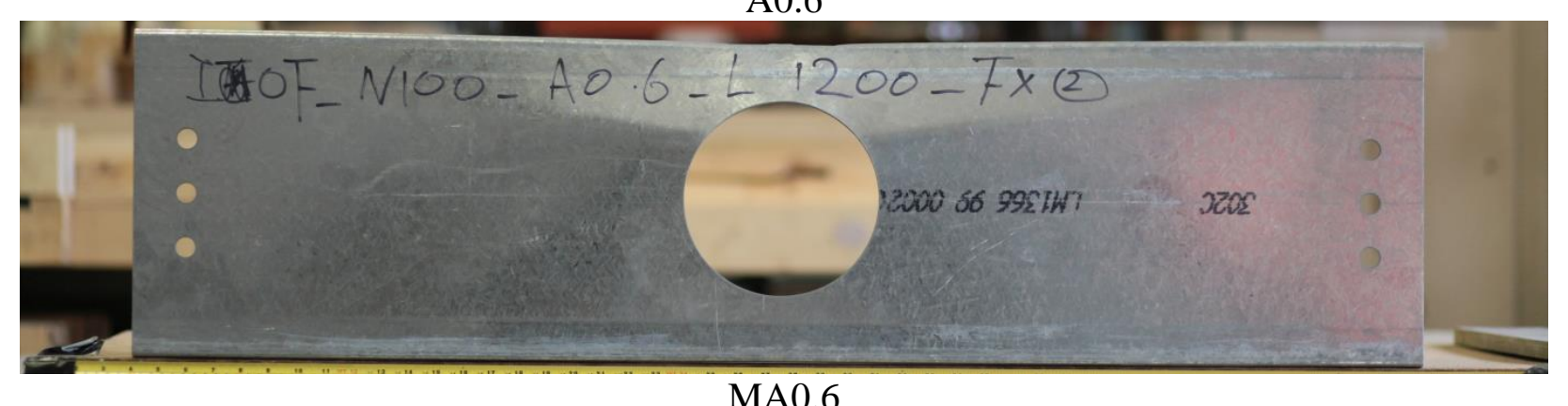

(b) Specimen for the flange fastened case

Fig.9 Typical failure modes of the specimens 


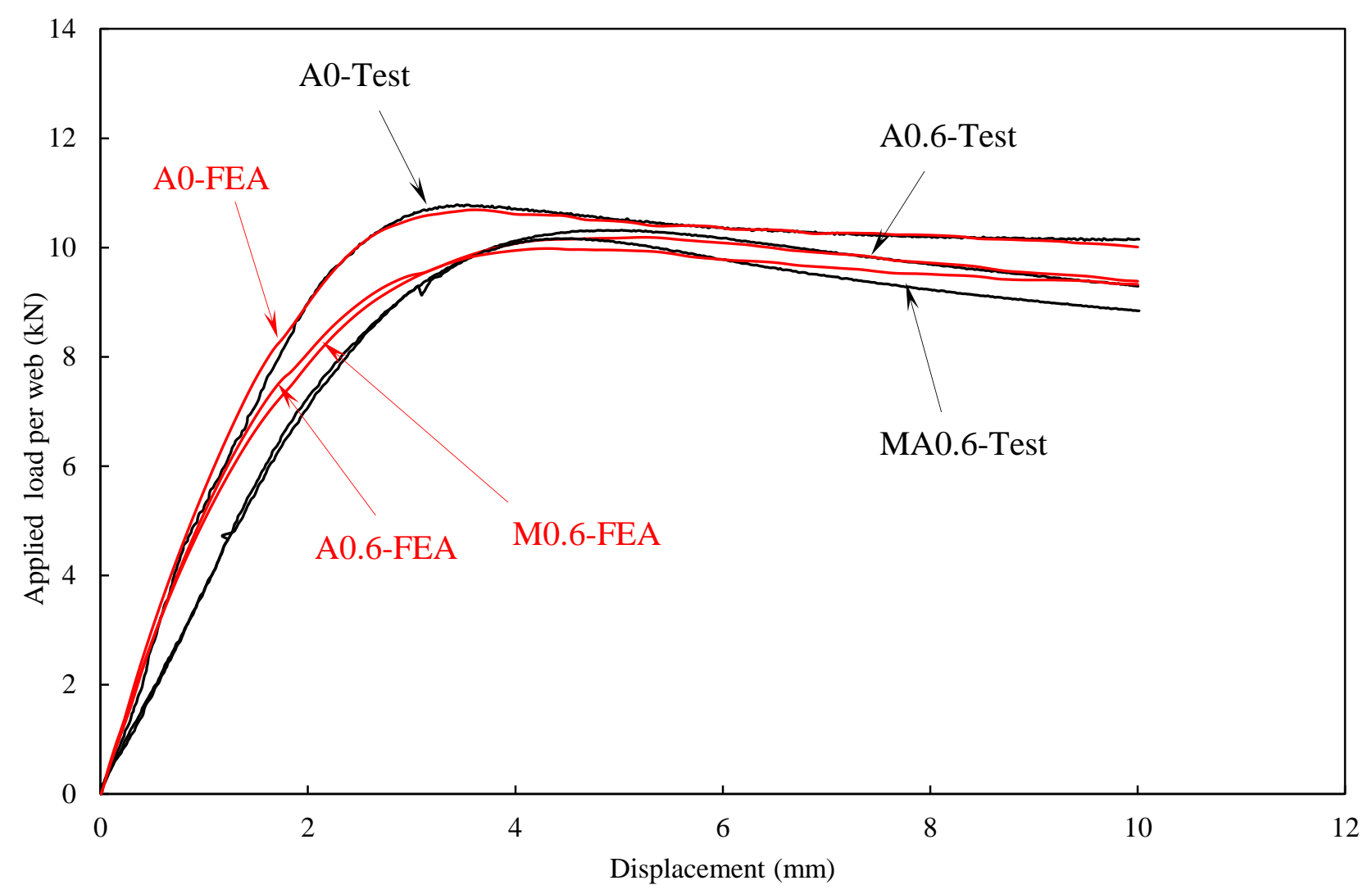

Fig.10 Comparison of web deformation curves for specimen $142 \times 60 \times 13-\mathrm{t} 1.3-\mathrm{N} 100-\mathrm{FR}$

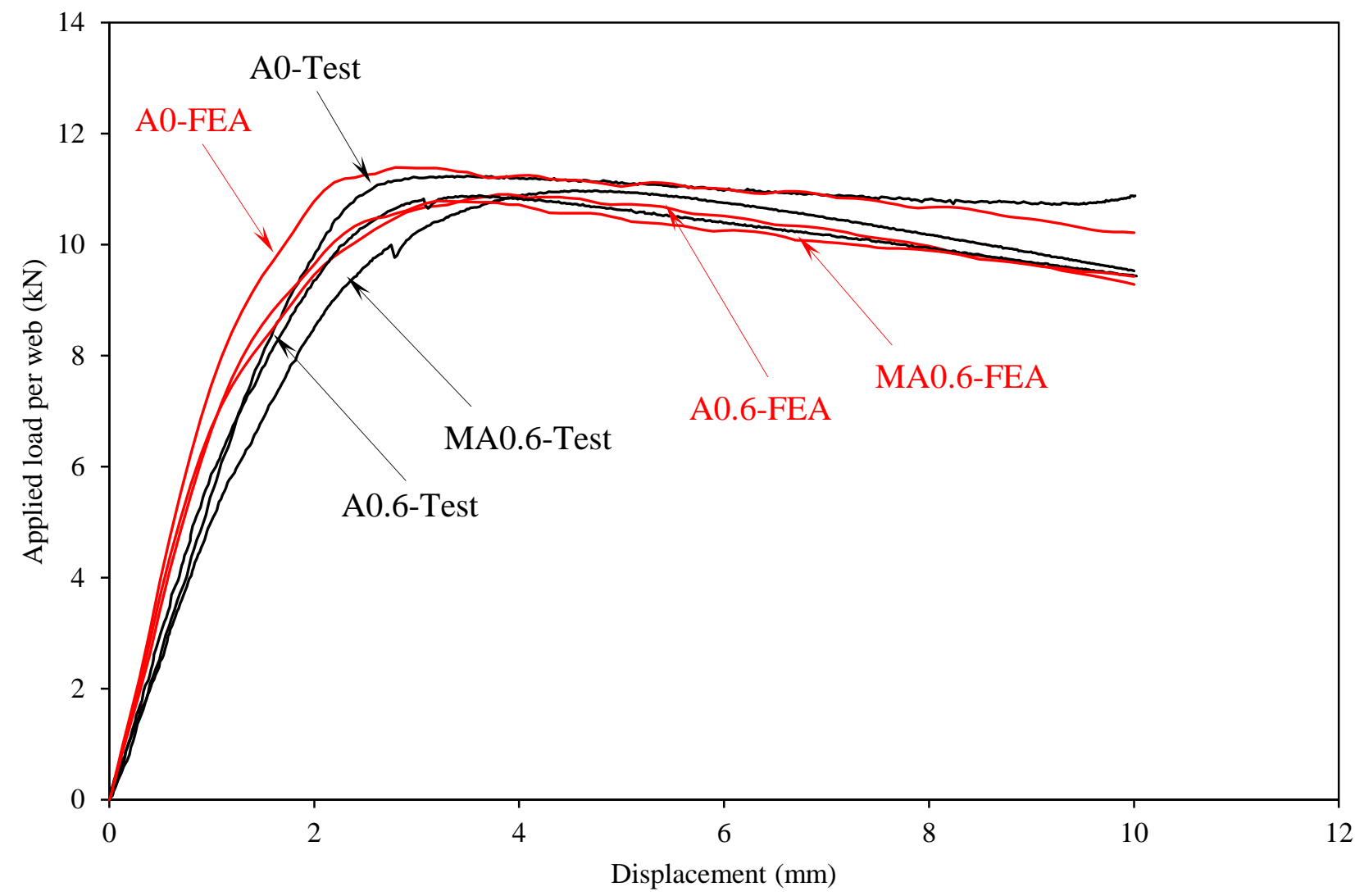

Fig.11 Comparison of web deformation curves for specimen $142 \times 60 \times 13-t 1.3-N 100-F X$ 